\title{
Catalytic Oxidation of Lignin in Solvent Systems for Production of Renewable Chemicals: A Review
}

\author{
Chongbo Cheng ${ }^{1}$, Jinzhi Wang ${ }^{1}$, Dekui Shen ${ }^{1, *}$, Jiangtao Xue ${ }^{2}$, Sipian Guan ${ }^{2}$, Sai Gu ${ }^{3}$ and \\ Kai Hong Luo ${ }^{4}$ \\ 1 Key Lab of Thermal Energy Conversion and Control of MoE, Southeast University, Nanjing 210096, China; \\ 220130473@seu.edu.cn (C.C.); 220160516@seu.edu.cn (J.W.) \\ 2 Jiangsu Frontier Electric Power Technology Co., Ltd., Nanjing 211102, China; ludong901122@sina.com (J.X.); \\ Parallel79@163.com (S.G.) \\ 3 Department of Chemical and Process Engineering, Faculty of Engineering and Physical Sciences, \\ University of Surrey, Surrey GU2 7XH, UK; sai.gu@surrey.ac.uk \\ 4 Department of Mechanical Engineering, University College London, London WC1E 7JE, UK; k.luo@ucl.ac.uk \\ * Correspondence: 101011398@seu.edu.cn; Tel.: +86-138-5170-6572
}

Academic Editor: Wolfgang Gindl-Altmutter

Received: 5 May 2017; Accepted: 16 June 2017; Published: 21 June 2017

\begin{abstract}
Lignin as the most abundant source of aromatic chemicals in nature has attracted a great deal of attention in both academia and industry. Solvolysis is one of the promising methods to convert lignin to a number of petroleum-based aromatic chemicals. The process involving the depolymerization of the lignin macromolecule and repolymerization of fragments is complicated influenced by heating methods, reaction conditions, presence of a catalyst and solvent systems. Recently, numerous investigations attempted unveiling the inherent mechanism of this process in order to promote the production of valuable aromatics. Oxidative solvolysis of lignin can produce a number of the functionalized monomeric or oligomeric chemicals. A number of research groups should be greatly appreciated with regard to their contributions on the following two concerns: (1) the cracking mechanism of inter-unit linkages during the oxidative solvolysis of lignin; and (2) the development of novel catalysts for oxidative solvolysis of lignin and their performance. Investigations on lignin oxidative solvolysis are extensively overviewed in this work, concerning the above issues and the way-forward for lignin refinery.
\end{abstract}

Keywords: biomass; lignin depolymerization; oxidative solvolysis; catalysis

\section{Introduction}

Biomass is an abundant renewable feedstock for the production of fuels, chemicals, and energy. Nowadays, about $10 \%$ of the world's primary energy is from biomass [1]. Biomass is primarily used to generate heat and power, and it stands as the fourth largest source of energy in the word (after oil, coal, and natural gas) [2]. Fuels produced from biomass-refinery processes are replacing the fossil-based fuels in the daily life [3]. However, the use of biomass components and derivatives as the raw feedstocks for the chemical industry is still in the fledging stages [4-8]. With the pressure of the price of fossil fuels and the high cost of biorefinery processes of biomass, more and more attention has been paid on the production of value-added chemicals from biomass.

Biomass consists of three valuable fractions: $38-50 \%$ cellulose composed of semi-crystalline polysaccharide, 23-32\% hemicellulose composed of amorphous multicomponent polysaccharide, and $15-25 \%$ lignin composed of amorphous phenylpropanoid polymer $[9,10]$. Hemicellulose has important applications for biofuel production and for the generation of valuable chemical intermediates (e.g., furfural) [11]; cellulose can be decomposed into valuable products such as biofuels and platform 
chemicals (including levulinic and formic acids, gammavalerolactone and derived products) [12]; and lignin is the most underutilized fraction, only approximately $2 \%$ of the lignin available from the pulp and paper industry is commercially used while the remainder is burned as a low value fuel [13]. There is a general lack of efficient processes for the utilization of lignin regarded as the most important renewable source of aromatics on the planet [14]. It becomes highly desirable to develop efficient technologies for the conversion of lignin to aromatic chemicals [15-17].

In the past decades, several strategies have been employed for lignin valorization, such as pyrolysis and gasification [18-23]. Lignin valorization in solvent systems for the production of renewable aromatic chemicals has attracted ever-increasing attention during recent years. The methodology for lignin depolymerization (LDP) in solvent systems can be categorized as hydrolysis, hydrogenolysis, oxidation and a two-step LDP. Lange et al. [3] and Chatel et al. [24,25] have published reviews on catalytic oxidation for lignin valorization into value-added chemicals. Some relevant reviews on bond cleavage mechanisms during lignin depolymerization have been published [26] and the separation and purification processes in lignin depolymerization have been reviewed recently [27]. Catalysis is regarded as a key factor to fulfill the promise of lignin depolymerization to specific products. Catalytic (homogeneous/heterogeneous) conversion of lignin for production of aromatic chemicals has also been reviewed in recent years [1,28-31]. Lignin oxidative solvolysis has been widely applied in the bleaching process for pulping industry due to its economic feasibility [32,33]. Phenolic products with low molecular weight were detected as the primary products from the oxidative solvolysis of lignin [33]. Organometallic catalyzed oxidation, biomimetic oxidation and enzyme-based oxidation have been studied [3,34,35], aiming at the cleavage of the designated inter-unit linkages [27]. Fundamental research on understanding and controlling the oxidative process is essential for promoting the production of specific valuable compounds [33].

The chemical structure and morphological properties of lignin are briefly introduced in this work, regarding the typical inter-unit linkages and lignin-related model compounds. Catalytic oxidation of lignin and lignin model compounds in solvent systems are then comprehensively overviewed, concentrating on the cracking of the inter-unit linkages and the effect of catalyst and solvent on the production of renewable aromatic chemicals.

\section{Chemical Structure of Lignin}

The roles of lignin in plants are to afford structural strength, protect the plants from degradation and enable the water conduction system connecting roots with leaves. Lignin is composed of p-hydroxyphenyl (H), guaiacyl (G) and syringyl (S) units linked by $\mathrm{C}-\mathrm{O}$ or $\mathrm{C}-\mathrm{C}$ bonds, which exhibit a complex three-dimensional amorphous structure. The content and chemical structure of lignin are primarily influenced by its sources and isolation methods. The chemical structure for lignin from different sources is different in terms of proportion of $p$-coumaryl-alcohol, coniferyl-alcohol, and sinapyl-alcohol (C9 unit) (Figure 1a). More than 95\% of guaiacyl units (that derived from coniferyl alcohol) are estimated to be in softwood lignin, while the proportions of coniferyl-alcohols and sinapyl-alcohols are approximately equal in hardwood lignin. Herbaceous biomass (e.g., straw) lignin and woody lignin are of different chemical structures because of the extra content of $p$-hydroxyphenyl units and significant amounts of hydroxycinnamic acid (mainly $p$-coumaric acid). The proportions of $p$-coumaryl-, coniferyl- and sinapyl-alcohols in lignin depend on sources of lignin.

Lignin units are linked by either $\mathrm{C}-\mathrm{O}$ or $\mathrm{C}-\mathrm{C}$ bonds. More than two-thirds of the total linkages are $\mathrm{C}-\mathrm{O}$ bonds while the others are $\mathrm{C}-\mathrm{C}$ bonds in native lignin $[1,36]$. The carbon atoms in aromatic moieties are numbered as 1-6 and those in the aliphatic side chains of the units are labeled as $\alpha, \beta$, and $\gamma$ to distinguish various types of linkages between two structural units. The $\beta$-position is generally favored by coupling other units, leading to $\beta-\mathrm{O}-4, \beta-\beta, \beta-1$ and $\beta-5$ becoming main linkages among the units of lignin [28,37-39]. The most common linkage in lignin is the $\beta-\mathrm{O}-4$ ether bond, accounting for 45 to $48 \%$ in native lignin [40,41]. Other linkages include $\alpha-\mathrm{O}-4,4-\mathrm{O}-5,5-5$, etc. The linkages in 
lignin are illustrated in Figure 1b, while the proportion of these linkages and the functional groups depends on the lignin sources and extraction methods [28,42,43].

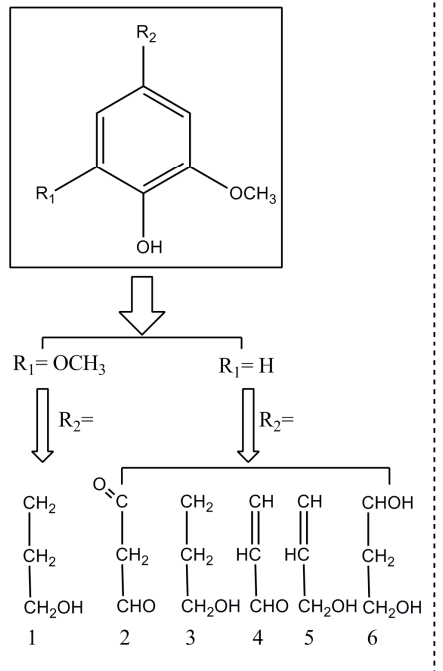

(a) The structure of monomer $\mathrm{C} 9$ units

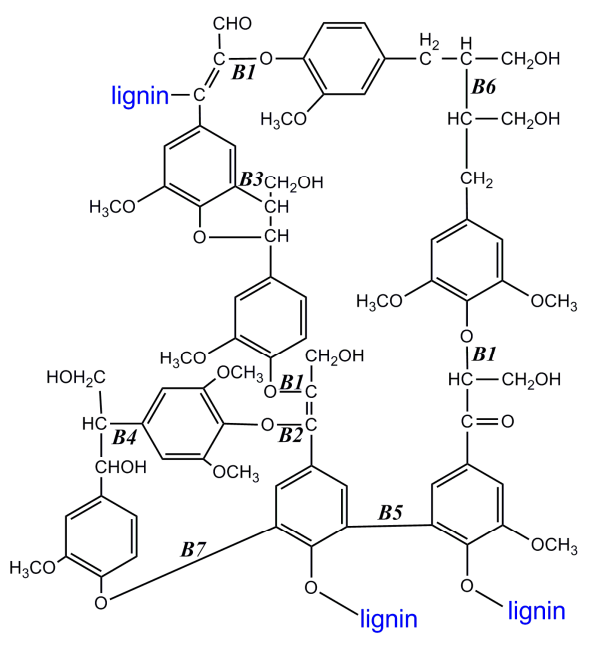

(b) The proposed lignin structure with several linkages

Figure 1. (a) Schematic of the structure of monomer C9 units; and (b) schematic of the proposed lignin structure with several linkages (B1: $\beta-\mathrm{O}-4, \mathrm{~B} 2: \alpha-\mathrm{O}-4, \mathrm{~B} 3: \beta-5, \mathrm{~B} 4: \beta-1, \mathrm{~B} 5: 5-5, \mathrm{~B} 6$ : $\beta-\beta, \mathrm{B} 7: 4-\mathrm{O}-5)$ [44], reproduced with permission from Springer.

Lignin-related model compounds are widely employed for better understanding of the cracking mechanism of the specific bonds in lignin. The most widely-reported model compounds and linkages containing aromatic or aliphatic ethers are shown in Figure 2 . The synthetic methods for making $\beta-\mathrm{O}-4$ model compounds [45], $\beta-5$ model compounds [46], $\beta-1$ model compounds $[47,48]$ and $\beta-\beta$ model compounds [49] have been reported in the literature. However, due to the lack of complexity of these models compared with lignin itself, the application of model compound in the development of selective LDP has been restricted [46]. Unlike a wide variety of trimer, tetramer, hexamer and polymer lignin model compounds containing only $\beta-\mathrm{O}-4$ linkage, Ouyang et al. [50] synthesized a lignin model compound composed of three guaiacyl structural units linked by $\alpha-\mathrm{O}-4$ and $\beta-\mathrm{O}-4$ ether bonds, via a three-step sequence method assisted with microwave irradiation. Sheldrake et al. [46] also reported a flexible, efficient and convergent preparation method for synthesizing model lignin hexamers and octamers linked by $\beta-\mathrm{O}-4,5-5^{\prime}$ and $\beta-5$. These lignin model compounds can reflect some natural information of lignin, giving a better understanding of the inherent mechanism of lignin depolymerization processes. Other novel approaches for synthesizing the model compounds that are more accurate in mimicking characteristics of lignin are still required.

Solvolysis is a promising method for converting lignin to various valuable aromatic chemicals. The lignin macromolecule depolymerization and fragments repolymerization are involved in this process, which is conducted by using different catalysts, solvent systems, experimental conditions and even heating methods. The depolymerization of lignin to renewable aromatic chemicals is difficult due to the thermally stable, amorphous and complex structure of lignin. Lignin depolymerization often necessitates harsh conditions to break the stable structure of lignin. Under such conditions, the undesired repolymerization of fragments is favored, resulting in a decrease of product yield. The target linkages of lignin might be hard to access by heterogeneous catalysts because of the steric hindrance of the lignin amorphous backbone. Although the target linkages of lignin could access by homogeneous catalysts, it is difficult to separate homogeneous catalysts from the liquid products. The variability of a large number of substructural units in lignin would result in different catalytic reaction rates at different sites. A number of lignin sources from different isolation methods should be examined concerning the selection of feedstock for LDP. 

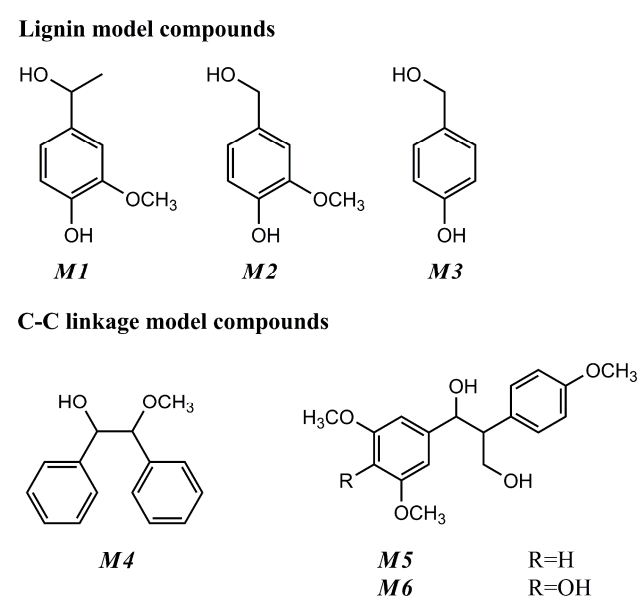

C-O linkage model compounds

$\alpha-\mathrm{O}-4$<smiles>c1ccc(COc2ccccc2)cc1</smiles><smiles>OC(COc1ccccc1)c1ccccc1</smiles>

M8
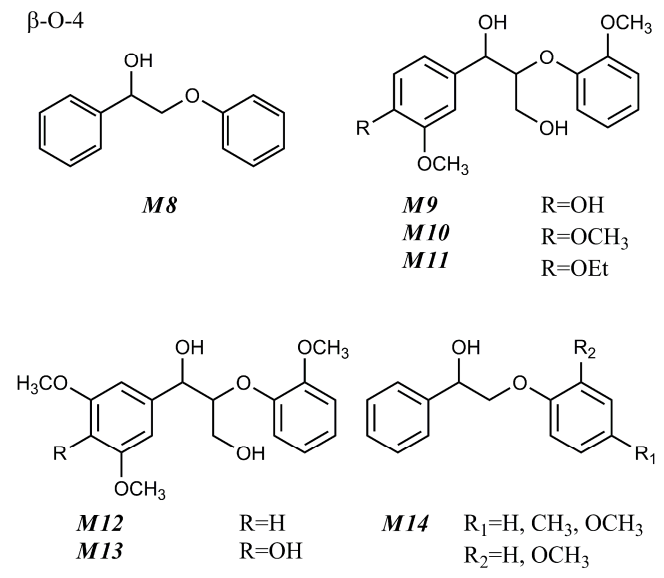

Figure 2. Lignin-related model compounds with different inter-unit linkages and functional groups.

\subsection{Kraft Lignin}

Kraft pulping is the predominant chemical pulping process around the world. This process is directed at temperatures in a range of $150-180{ }^{\circ} \mathrm{C}$ for around two hours and at high $\mathrm{pH}$ with the presence of considerable amounts of aqueous sulfide, sulfhydryl and polysulfide ions. Thus, the native lignin will undergo dramatic chemical and structural changes due to these severe conditions, which makes it difficult to be depolymerized to fragments in the subsequent processes. The percentage of lignin in the black liquor generated by kraft pulping ranges from 29 to $45 \%$ for cook of paper grade and 8 to $16 \%$ for cook of liner grade [51] and the percentage of kraft black liquor lignin extracted from hardwood is generally lower than that of softwood.

\subsection{Sulfite Lignin}

As kraft pulping becomes the dominant pulping process all around world, just about $10 \%$ of the pulp is produced by sulfite pulping process now [52]. Sulfite pulping is conducted under $\mathrm{pH} 2-12$, depending on the cationic composition of the pulping liquor. Nearly all sulfite pulping processes are acidic, and calcium or magnesium $\left(\mathrm{Ca}^{2+} / \mathrm{Mg}^{2+}\right)$ are used as the counterions, while, in higher $\mathrm{pH}$ environments, sodium or ammonium are usually used instead of $\mathrm{Ca} / \mathrm{Mg}$. Due to the sulfite 
presence, lignin is rendered soluble throughout the full range of $\mathrm{pH}$; it cannot simply be isolated by $\mathrm{pH}$ adjustment. As mixtures with only $70-75 \%$ actually lignin, commercial sulfite lignin shows wide molecular weight profiles and variable grades of sulfonation, making it difficult to be applied in lignin depolymerization. The average molecular weight of sulfite lignin from softwood is notably higher that of the sulfite lignin from hardwood.

\subsection{Organosolv Lignin}

Organosolv lignin, derived from organosolv pulping process, is designed to dissolve lignin from plant cell walls by using a high proportion of an organic solvent (e.g., dioxane) in the cooking liquor [53]. Compared to kraft and sulfite pulping, organosolv pulping is a more environmentally benign pathway. Organosolv lignin reserves a large extent of its original structure in the form of original inter-unit linkages (e.g., $\beta$-O-4 linkage), which can be used as an appropriate lignin sample for subsequent conversion and valorization.

\subsection{Pyrolytic Lignin}

Pyrolytic lignin has unusual structural properties featured by its $\mathrm{C} 8$ basic unit skeleton and lower average molecular weight $[54,55]$. The average molecular weight of the pyrolytic lignin was reported to be within a range of 650-1300 Da [55]. Pyrolytic lignin is composed of some thermally ejected oligomers and the side chains in pyrolytic lignin are primarily in the form of inter-unit $\mathrm{C}-\mathrm{C}$ linkages, leading to the difficulty of its application in LDP.

\subsection{Dilute Acid Lignin}

Diluted acids (e.g., $\mathrm{H}_{2} \mathrm{SO}_{4}$ and $\mathrm{HCl}$ ) pulping have been applied in all kinds of lignocellulosic materials. Diluted acid pulping is generally conducted at a temperature of $>160^{\circ} \mathrm{C}$ with the presence of mineral acids as a catalyst. The $\mathrm{C}-\mathrm{O}$ linkages as well as ester linkages are partially cracked during the diluted acid pulping process. This process may also undermine the three-dimensional amorphous structure in lignin and produce small lignin fragments with the increased proportion of hydroxyl groups [56,57]. Thus, lignin should be removed under benign conditions if it is considered as a feedstock for further chemical production.

\subsection{Steam Explosion Lignin}

The steam explosion pulping process is a fast processing method for lignocellulose, which releases single biomass components via steam impregnation under pressure and then the fast release of pressure [51]. For example, the disposal of wood or bagasse is conducted under high-pressure steam at a short contact time. More than $90 \%$ of lignin in hardwood can be recovered from the steam explosion pulping process. The properties of steam explosion lignin are similar to that of organosolv lignin, showing both a higher solubility and a lower molecular weight in an organic solvent. It is also composed of phenolic oligomers with 3 to 12 benzene rings. As a result, steam explosion lignin has potential for producing renewable chemicals through LDP.

\section{Oxidative Solvolysis of Lignin}

Oxidative solvolysis of lignin is a widely used and efficient strategy for producing multiple aromatic monomers. The oxidative solvolysis of lignin reaction includes the cracking of $\mathrm{C}-\mathrm{O}$ bonds, $\mathrm{C}-\mathrm{C}$ bonds in lignin. Aromatic aldehydes and carboxylic acids are the main products from oxidative solvolysis of lignin with different kinds of homogeneous catalysts. $\mathrm{O}_{2}, \mathrm{H}_{2} \mathrm{O}_{2}$, metal oxides and nitrobenzene have been considered as effective oxidation agents. In this section, the effect of catalyst and solvent on the production of valuable aromatic chemicals in the catalytic oxidation of lignin process will be discussed. Research on oxidative solvolysis of raw lignin (Kraft lignin, Organosolv lignin, etc.) to the aromatic products is summarized in Table 1. 
Table 1. Summary of oxidative depolymerization of the raw lignin material.

\begin{tabular}{|c|c|c|c|c|c|c|c|}
\hline Entry & Feedstock & Conditions & Solvent & Catalyst & Products & Yield & Ref \\
\hline 1 & Organosolv lignin (from M. giganteus) & $80^{\circ} \mathrm{C}, 24 \mathrm{~h}$, air & $\begin{array}{c}\text { Acetonitrile-THF or ethyl } \\
\text { acetate-THF }\end{array}$ & $\begin{array}{l}\text { Vanadium complexes bearing Schiff } \\
\text { base ligands }\end{array}$ & $\begin{array}{l}\text { Monophenolic compounds (vanillin, } \\
\text { syringic acid, syringaldehyde) }\end{array}$ & $\begin{array}{c}0.78 \mathrm{wt} \%, 0.67 \mathrm{wt} \%, 0.59 \mathrm{wt} \% \\
\quad(\text { Catalyst }=\text { Complex } 3)\end{array}$ & {$[58]$} \\
\hline 2 & Organosolv lignin & $100{ }^{\circ} \mathrm{C}, 18 \mathrm{~h}, 0.8 \mathrm{MPa}$ synthetic air & Ethyl acetate & $\begin{array}{c}\text { Vanadium complexes and other } \\
\text { organometallic catalysts }\end{array}$ & Bio-oil & $M w=575 \mathrm{Da}($ Catalyst $=$ Complex 2$)$ & [59] \\
\hline 3 & Organosolv lignin and Kraft lignin & $100^{\circ} \mathrm{C}, 8 \mathrm{~h}, \mathrm{H}_{2} \mathrm{O}_{2}$ & DMSO and acetic acid & \{Fe-DABCO $\}$ & Bio-oil & 1 & {$[60]$} \\
\hline 4 & Organosolv lignin & $80^{\circ} \mathrm{C}, 24 \mathrm{~h}$, air & Acetonitrile-THF & $\begin{array}{l}\text { Co(salen) supported on } \\
\text { graphene oxide }\end{array}$ & Vanillin (main) & $3067 \mathrm{~g}$ & [61] \\
\hline 5 & Organosolv lignin and Kraft lignin & $135^{\circ} \mathrm{C}, 40 \mathrm{~h}, 1.0 \mathrm{MPa} \mathrm{O}_{2}$ & Pyridine & $\begin{array}{c}\mathrm{V}(\mathrm{acac})_{3} \text { and } \mathrm{Cu}\left(\mathrm{NO}_{3}\right)_{2} \cdot 3 \mathrm{H}_{2} \mathrm{O} \text { or } \\
\mathrm{HTC}-\mathrm{Cu}-\mathrm{V}\end{array}$ & Bio-oil & $M \mathrm{w}=300 \mathrm{Da}$ & {$[62]$} \\
\hline 6 & $\begin{array}{l}\text { Hydrolytic sugar cane lignin and red } \\
\text { spruce kraft lignin }\end{array}$ & $25^{\circ} \mathrm{C}, 24 \mathrm{~h}, \mathrm{H}_{2} \mathrm{O}_{2}$ & Acetic acid & $\begin{array}{l}\text { MTO or poly(4-vinylpyridine)/MTO } \\
\text { or polystyrene/MTO }\end{array}$ & Bio-oil & / & [63] \\
\hline 7 & Organosolv ligin (from birch wood) & $140^{\circ} \mathrm{C}, 24 \mathrm{~h}, 0.1 \mathrm{MPa} \mathrm{O}_{2}$ & $\begin{array}{c}\mathrm{H}_{2} \mathrm{O} \text {, tert-butyl } \\
\text { hydroperoxide (TBHP) }\end{array}$ & $\begin{array}{c}\text { Nitrogen-containing graphene } \\
\text { material (LCN) }\end{array}$ & Bio-oil & $45.8 \mathrm{wt} \%$ & {$[64]$} \\
\hline 8 & Alkali lignin & $175-225^{\circ} \mathrm{C}, 0-1 \mathrm{~h}, 0.5-1.5 \mathrm{MPa} \mathrm{O}_{2}$ & Water & $\mathrm{NaOH}$ & $\begin{array}{l}\text { Formic acid, acetic acid, succinic acid, } \\
\text { oxalic acid, glutaconic acid }\end{array}$ & $44.0 \mathrm{wt} \%$ & {$[65]$} \\
\hline 9 & Wheat alkali lignin & $150^{\circ} \mathrm{C}, 1 \mathrm{~h}, \mathrm{H}_{2} \mathrm{O}_{2}$ & $\begin{array}{c}\text { Water/methanol/1,4-dioxane/ } \\
\text { tetrahydrofuran/ethanol }\end{array}$ & $\mathrm{CuO}, \mathrm{Fe}_{2}\left(\mathrm{SO}_{4}\right)_{3}$ and $\mathrm{NaOH}$ & Monophenolic compounds & $17.92 \mathrm{wt} \%$ (in methanol-water) & [66] \\
\hline 10 & Wood lignin from Loblolly pine & $80^{\circ} \mathrm{C}, 24 \mathrm{~h}, 0.27 / 1.24 \mathrm{MPa} \mathrm{O}_{2}$ & Methanol & $\begin{array}{l}\text { Copper-phenanthroline complex } \\
\text { and } \mathrm{NaOH}\end{array}$ & Vanillic acid, vanillin & $3.5 \mathrm{wt} \%, 12.6 \mathrm{wt} \%$ & {$[67]$} \\
\hline 11 & Kraft lignin & $170^{\circ} \mathrm{C}, 0.3 \mathrm{~h}, 0.5 \mathrm{MPaO}_{2}$ & Methanol-water and $\mathrm{H}_{2} \mathrm{SO}_{4}$ & $\mathrm{H}_{3} \mathrm{PMo}_{12} \mathrm{O}_{40}$ & Vanillin, methyl vanillate & $5.2 \mathrm{wt} \%$ & {$[68]$} \\
\hline 12 & Kraft lignin & $170^{\circ} \mathrm{C}, 0.3 \mathrm{~h}, 1.0 \mathrm{MPa} \mathrm{O}_{2}$ & Methanol-water and $\mathrm{H}_{2} \mathrm{SO}_{4}$ & $\mathrm{H}_{3} \mathrm{PMo}_{12} \mathrm{O}_{40}$ & Vanillin, methyl vanillate & $4.6 \mathrm{wt} \%, 4.2 \mathrm{wt} \%$ & {$[69]$} \\
\hline 13 & Kraft lignin & $170^{\circ} \mathrm{C}, 1 \mathrm{~h}, 1.0 \mathrm{MPa} \mathrm{O}_{2}$ & Methanol-water and $\mathrm{H}_{2} \mathrm{SO}_{4}$ & $\begin{array}{l}\mathrm{CuSO}_{4} ; \mathrm{FeCl}_{3} ; \\
\mathrm{CuCl}_{2} ; \mathrm{CoCl}_{2}\end{array}$ & Vanillin, methyl vanillate & $6.3 \mathrm{wt} \%$ & [70] \\
\hline 14 & Kraft lignin & $45^{\circ} \mathrm{C}, 1 \mathrm{~h}, \mathrm{H}_{2} \mathrm{O}_{2}$ & Acetone-water & Metal salt catalysts & Vanillin-based monomers & $0.51 \mathrm{wt} \%$ & {$[71]$} \\
\hline 15 & Organosolv lignin & $180^{\circ} \mathrm{C}, 2 \mathrm{~h}, 13.8 \mathrm{MPa}$ air & Acetic Acid-water & $\mathrm{Co} / \mathrm{Mn} / \mathrm{Zr} / \mathrm{Br}$ mixture & $\begin{array}{c}\text { Vanillin, vanillin acid, } \\
\text { syringaldehyde, syringic acid }\end{array}$ & $\begin{array}{c}0.99 \mathrm{wt} \%, 2.91 \mathrm{wt} \%, 2.52 \mathrm{wt} \%, \\
4.51 \mathrm{wt} \%\end{array}$ & {$[72]$} \\
\hline 16 & Organosolv beech wood lignin & $200 \mathrm{~W}, 5-30 \mathrm{~min}, \mathrm{H}_{2} \mathrm{O}_{2}$ & NaOH solution & La/SBA-15 & Vanillin, syringaldehyde & $9.94 \mathrm{wt} \%, 15.66 \mathrm{wt} \%$ & {$[73]$} \\
\hline 17 & Organosolv lignin & $185^{\circ} \mathrm{C}, 24 \mathrm{~h}, 0.1 \mathrm{MPa} \mathrm{O}_{2}$ & Methanol & $\mathrm{Pd} / \mathrm{CeO}_{2}$ & $\begin{array}{c}\text { Vanillin, guaiacol, } \\
\text { 4-hydroxybenzaldehyde }\end{array}$ & $5.2 \mathrm{wt} \%, 0.87 \mathrm{wt} \%, 2.4 \mathrm{wt} \%$ & {$[74]$} \\
\hline 18 & Enzymatic hydrolysis lignin & $120^{\circ} \mathrm{C}, 0-3 \mathrm{~h}, 0.5 \mathrm{MPa} \mathrm{O}_{2}$ & $\mathrm{NaOH}$ solution & $\mathrm{LaMnO}_{3}$ & $\begin{array}{l}\text { Vanillin, } p \text {-hydroxybenzyl } \\
\text { aldehyde, syringaldehyde }\end{array}$ & $4.32 \mathrm{wt} \%, 2.03 \mathrm{wt} \%, 9.33 \mathrm{wt} \%$ & {$[75]$} \\
\hline 19 & Enzymatic hydrolysis lignin & $120^{\circ} \mathrm{C}, 0-3 \mathrm{~h}, 0.5 \mathrm{MPa} \mathrm{O}_{2}$ & $\mathrm{NaOH}$ solution & $\mathrm{LaCoO}_{3}$ & $\begin{array}{l}\text { Vanillin, }, \text {-hydroxybenzyl } \\
\text { aldehyde, syringaldehyde }\end{array}$ & $4.55 \mathrm{wt} \%, 2.23 \mathrm{wt} \%, 9.99 \mathrm{wt} \%$ & {$[76]$} \\
\hline
\end{tabular}




\subsection{Effects of Catalysts}

Catalysts are involved in most cases of the oxidative depolymerization of lignin to produce particular products and even perform chemoselective oxidation of a particular linkage in lignin $[77,78]$. The catalysts widely used for the oxidative solvolysis of lignin can be divided into five groups: organometallic catalysts, metal-free-organic catalysts, acid/base catalysts, metal salts catalysts, and zeolite catalysts (heterogeneous catalyst).

\subsubsection{Organometallic Catalysts}

Several studies have reported on the oxidative solvolysis of raw lignin by using an organometallic catalyst. Chan et al. [58] demonstrated that a series of vanadium complexes bearing Schiff base ligands (e.g., Complex 3 in Figure 3) could be used to degrade organosolv lignin (extracted from Miscanthus giganteus using dioxane, acetone, and ethanol) into phenolic products in acetonitrile-THF or ethyl acetate-THF. After $24 \mathrm{~h}$ of reaction at $80{ }^{\circ} \mathrm{C}$ under air, vanillin, syringic acid and syringaldehyde were the most common degradation products, resulting from the guaiacyl and syringyl units of lignin, respectively (Table 1, Entry 1). Pretreatment and isolation methods could remarkably alter the structure of lignin and thus affect the reactivity of lignin toward catalysts. Then, vanadium Complexes 1, 2 and 4 (Figure 3) and other organometallic catalysts such as 4-acetamido-TEMPO/acid (TEMPO = 2,2,6,6-tetramethylpiperidine-1-oxyl) and (salen)cobalt(II) were also used in the catalytic oxidation of organosolv lignin [59]. Though most catalysts oxidized the lignin extracts, bis(8-oxy-quinoline) oxovanadium and bis(phenolate)pyridine oxovanadium catalyst, Complex 2 and Complex 5 (Figure 3), respectively, exhibited the best performance for depolymerization/oxidation of organosolv lignin. After $18 \mathrm{~h}$ of reaction at $100{ }^{\circ} \mathrm{C}$ in $0.8 \mathrm{MPa}$ of synthetic air $\left(8 \% \mathrm{O}_{2}\right.$ in $\left.\mathrm{Ar}\right)$, the best depolymerization performance was exhibited by Complex 2 , which gave the largest molecular weight $\left(M_{\mathrm{W}}\right)$ shift and a considerable increase in the lower molecular weight products (Table 1, Entry 2). Iron complexes could also be suitable for oxidation of lignin. \{Fe-DABCO (DABCO $=1,4$-diazabicyclo[2.2.2]-octane) catalyst was presented for the cleavage of $\beta$-O-4 linkages in lignin in the presence of $\mathrm{H}_{2} \mathrm{O}_{2}$ [60]. After $8 \mathrm{~h}$ of reaction at $100{ }^{\circ} \mathrm{C}$, the mass maximum in the lignin sample had shifted from 3200 Da to around $2500 \mathrm{Da}$ (Table 1, Entry 3). GPC analysis showed that the mass maximum had shifted to lower masses in all lignin samples, providing evidence for the formation of low molecular weight products. In addition, all of the $\beta-\mathrm{O}-4$ linkages and resinol structures were degraded independent of the lignin pretreatment and isolation conditions.
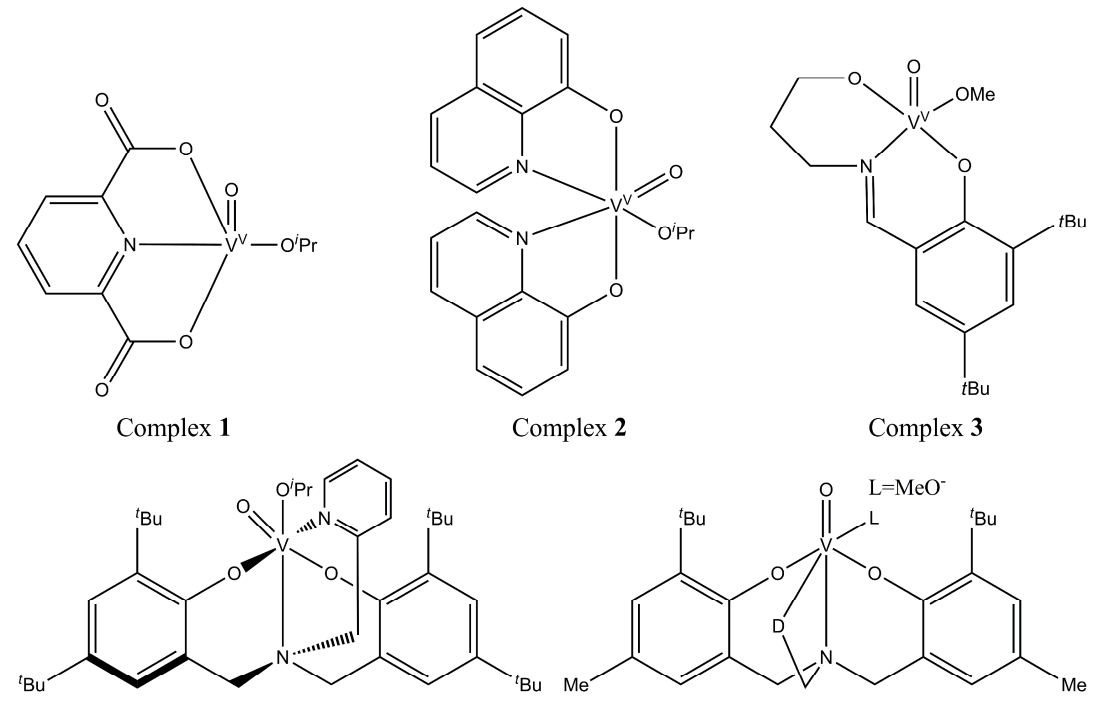

Complex 4

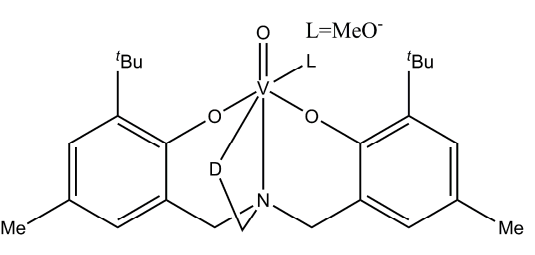

Complex $\mathbf{5}$

Figure 3. Schematics of the catalyst: vanadium Complexes 1-5. 
$\mathrm{Co}($ salen)/oxidant has been proven to be an efficient catalytic system for oxidation of phenolic and nonphenolic $\beta-\mathrm{O}-4$ aryl ether lignin model compounds $[79,80]$. To improve complexes' stability, selectivity, and recyclability, Co salen complexes were immobilized on graphene oxide (GO) (Co-GO) for the oxidation of lignin [61]. After $24 \mathrm{~h}$ of reaction at $80^{\circ} \mathrm{C}$ in air, organosolv lignin was converted to vanillin (the main product), vanillic acid, 1-(4-hydroxy-3-methoxyphenyl) ethanol, and other monomeric phenolic compounds (Table 1, Entry 4). The oxidation of aliphatic groups resulted in the formation of carbonyl compounds, cleavage of $\beta-\mathrm{O}-4$ bonds, demethylation of methoxy groups and formation of phenolic $\mathrm{OH}$ groups.

Recently, the first transition metal system using $\mathrm{O}_{2}$ as an oxidant for cleaving the resinol structure was reported [62]: An oxidative solvolysis of lignin with inexpensive transition-metal-containing hydrotalcites $(\mathrm{HTc}-\mathrm{Cu}-\mathrm{V})$ or combinations of $\mathrm{V}(\mathrm{acac})_{3}\left(\mathrm{acac}=\right.$ acetylacetonate) and $\mathrm{Cu}\left(\mathrm{NO}_{3}\right)_{2} \cdot 3 \mathrm{H}_{2} \mathrm{O}$ as catalysts. As the homogeneous copper and vanadium species from $\mathrm{V}(\mathrm{acac})_{3} / \mathrm{Cu}\left(\mathrm{NO}_{3}\right)_{2} \cdot 3 \mathrm{H}_{2} \mathrm{O}$ and the leached $\mathrm{HTc}-\mathrm{Cu}-\mathrm{V}$ were most probably very similar in nature, after $40 \mathrm{~h}$ of reaction at $135{ }^{\circ} \mathrm{C}$, the oxidative solvolysis of lignin afforded products of a mass of approximately $300 \mathrm{Da}$ by using copper-vanadium double-layered hydrotalcites or combined $\mathrm{V}(\mathrm{acac})_{3}(\mathrm{acac}=$ acetylacetonate) and $\mathrm{Cu}\left(\mathrm{NO}_{3}\right)_{2} \cdot 3 \mathrm{H}_{2} \mathrm{O}$ as catalysts (Table 1, Entry 5).

Methyltrioxo rhenium (MTO) acts as an active and efficient catalyst for the oxidation of phenolic and non-phenolic lignin model compounds representing the main bond patterns in native lignin resulting in the side-chain oxidation and aromatic ring cracking reaction [81]. Crestini et al. [63] developed immobilized MTO catalysts such as poly(4-vinylpyridine)/MTO and polystyrene/MTO as an easy recovery, reuse and low environmental impact catalyst, for the oxidation of lignin (Table 1 , Entry 6). Different reaction pathways occurred between soluble MTO and immobilized MTO catalysts in the oxidative solvolysis of lignin: compared to homogeneous MTO, immobilized MTO catalysts with lower Lewis acidity might direct their reactivity toward aliphatic $\mathrm{C}-\mathrm{H}$ insertion and Dakin-like reactions instead of oxidizing the aromatic ring. Consequently, these differences gave rise to the final product with a higher amount of free phenolic guaiacyl groups in the presence of immobilized MTO catalysts.

\subsubsection{Metal-Free-Organic Catalysts}

Some metal-free-organic catalysts have been identified as effective catalysts for the oxidation of $\beta-\mathrm{O}-4$ and $\alpha-\mathrm{O}-4$ types of lignin model compounds. Gao et al. [64] used nitrogen-containing graphene material (LCN) to convert birch wood lignin into depolymerized products in water and tert-butyl hydroperoxide solvent. LCN exhibited a similar catalytic behavior in the oxidation of lignin model compounds and birch wood lignin. The catalytic oxidation of benzylic $\mathrm{C}-\mathrm{H}$ and $\mathrm{C}-\mathrm{OH}$ bonds into carbonyl groups broke the $\mathrm{C}_{\alpha}-\mathrm{C}_{\beta}$ and $\mathrm{C}_{\alpha}-\mathrm{O}$ bonds, and further catalyzed the decomposition of some unstable aromatic compounds. Finally, $45.8 \mathrm{wt} \%$ bio-oil could be obtained from birch wood lignin after $24 \mathrm{~h}$ of reaction at $140{ }^{\circ} \mathrm{C}$ in the presence of $0.1 \mathrm{MPa} \mathrm{O}_{2}$ (Table 1, Entry 7).

\subsubsection{Acid/Base Catalysts}

$\mathrm{NaOH}$ and $\mathrm{KOH}$ are utilized most frequently in the alkaline oxidation of lignin. Ouyang et al. [82] reported the oxidative degradation of soda lignin assisted by microwave on $\mathrm{NaOH}$ catalyst $(\mathrm{pH}=11)$. Similarly, $\mathrm{Wu}$ et al. [83] reported the oxidative degradation of different lignin samples in $\mathrm{KOH}$ with $\mathrm{H}_{2} \mathrm{O}_{2}$ or $\mathrm{K}_{2} \mathrm{~S}_{2} \mathrm{O}_{8}$ to methanol, formate, carbonate, and oxalate. Even at near-ambient temperatures $\left(60^{\circ} \mathrm{C}\right),>90 \%$ consumption of lignin was observed after $24 \mathrm{~h}$. The microwave irradiation efficiently helped the degradation of lignin to produce high molecular weight compounds. The origin of the lignin, reaction temperature, oxidant concentration, and $\mathrm{pH}$ value also had impacts on the conversion efficiency. For example, higher reaction temperature and $\mathrm{O}_{2}$ concentration facilitated the yield of the final products but also gave rise to the repolymerization of lignin fragments. Maziero et al. [84] also reported that sugarcane bagasse lignin oxidized with $9.1 \% \mathrm{H}_{2} \mathrm{O}_{2}(\mathrm{~m} / v)$ at $\mathrm{pH}=13.3$ had the highest fragmentation, oxidation degree and stability. The oxidation of alkali lignin was performed on 
$\mathrm{NaOH}$ catalyst $(\mathrm{pH}=11)$ in the presence of $\mathrm{O}_{2}$ [65]. After 20 min of reaction, the maximum total yield of products (formic acid, acetic acid, succinic acid, oxalic acid, and glutaconic acid) of $44 \mathrm{wt} \% \mathrm{was}$ obtained at $225^{\circ} \mathrm{C}$ and $1 \mathrm{MPa} \mathrm{O}_{2}$ (Table 1, Entry 8).

Ouyang et al. [66] reported the oxidative solvolysis of lignin by using $\mathrm{H}_{2} \mathrm{O}_{2}$ as the oxidant and combination of $\mathrm{CuO}, \mathrm{Fe}_{2}\left(\mathrm{SO}_{4}\right)_{3}$ and $\mathrm{NaOH}$ as catalysts. $\mathrm{Cu}^{2+}$ could result in the removal of side chains from basic units of lignin forming some phenolic compounds while with $\mathrm{OOH}$ radicals generated by dissociation of $\mathrm{H}_{2} \mathrm{O}_{2}, \mathrm{Fe}^{3+}$ could form new reactive intermediates [85], facilitating oxidative solvolysis of lignin. The yield of monophenolic compounds with a higher amount of syringyl unit compounds (syringaldehyde, syringic acid, acetosyringone) reached $17.92 \mathrm{wt} \%$ in methanol/water $(1: 1(v / v))$ solvent at $150^{\circ} \mathrm{C}$ after $1 \mathrm{~h}$ reaction (Table 1, Entry 9). Wood lignin from loblolly pine was oxidized by 1,10-phenanthroline and copper (II) sulfate pentahydrate and $\mathrm{NaOH}$ catalysts in methanol solvent [67]. Finally, $3.5 \mathrm{wt} \%$ vanillic acid and $12.6 \mathrm{wt} \%$ vanillin could be obtained after $24 \mathrm{~h}$ of reaction at $80^{\circ} \mathrm{C}$ in the presence of $0.27 \mathrm{MPa} \mathrm{O}_{2}$ (Table 1, Entry 10).

\subsubsection{Metal Salt Catalysts}

Polyoxometalates (POMs) consists of a number of metal oxygen cluster anions. They are soluble in both water and organic solvents, and its redox potential is high enough to oxidize lignin basic units yet low enough to be reoxidized by $\mathrm{O}_{2}$. A series of POMs are capable of selectively degrading the residual lignin and, in turn, fully converting residual lignin into $\mathrm{CO}_{2}$ and $\mathrm{H}_{2} \mathrm{O}$ by wet oxidation [86]. The POM treatment of lignin leads to a sharp reduction in the content of $\alpha-\mathrm{OH} / \beta-\mathrm{O}-4$ inter-unit linkages, following demethylation. A high increase in carbonyl groups implies the loss of aromaticity in lignin, probably due to the conversion of aromatic rings to quinone moieties [86,87]. Voitl and Rohr [68] conducted the oxidative solvolysis of lignin by using aqueous POMs in the presence of alcohols for converting kraft lignin into chemicals. After $20 \mathrm{~min}$ of reaction, a total yield of products (vanillin and methyl vanillate) of $5.2 \mathrm{wt} \%$ could be obtained at $170{ }^{\circ} \mathrm{C}$ and $0.5 \mathrm{MPa} \mathrm{O}_{2}$ (Table 1, Entry 11). In a stirred batch reactor, vanillin $(4.6 \mathrm{wt} \%)$ and methyl vanillate $(4.2 \mathrm{wt} \%)$ could be obtained at $170{ }^{\circ} \mathrm{C}$ and 1.0 MPa $\mathrm{O}_{2}$ (Table 1, Entry 12) [69].

Transition metal salts are another kind of homogeneous catalysts for lignin oxidation, which have a wide range of cation redox potential. Werhan et al. [70] reported the acidic oxidation of kraft lignin with different transition metal salts $\left(\mathrm{CuSO}_{4}, \mathrm{FeCl}_{3}, \mathrm{CuCl}_{2}, \mathrm{CoCl}_{2}\right)$. The maximum yield of vanillin gained was invariably higher for the transition metal salts than for the $\mathrm{POMs}$. $\mathrm{CoCl}_{2}$ showed the best performance among the investigated catalysts with a maximum yield of $6.3 \mathrm{wt} \%$ (vanillin and methyl vanillate) at $170{ }^{\circ} \mathrm{C}$ and $1.0 \mathrm{MPa} \mathrm{O}_{2}$ (Table 1, Entry 13). In addition, the $\mathrm{H}_{2} \mathrm{O}_{2}$ mediated oxidative solvolysis of kraft lignin was also investigated in the presence of different metal salt catalysts $\left(\mathrm{Fe}_{2}\left(\mathrm{SO}_{4}\right)_{3}, \mathrm{Fe}\left(\mathrm{NO}_{3}\right) \cdot 9 \mathrm{H}_{2} \mathrm{O}, \mathrm{Mn}\left(\mathrm{SO}_{4}\right) \cdot \mathrm{H}_{2} \mathrm{O}, \mathrm{Bi}_{2}\left(\mathrm{SO}_{4}\right)_{3}, \mathrm{Bi}\left(\mathrm{NO}_{3}\right)_{3} \cdot 5 \mathrm{H}_{2} \mathrm{O}, \mathrm{H}_{2} \mathrm{WO}_{4}\right.$, and $\left.\mathrm{Na}_{2} \mathrm{WO}_{4} \cdot 2 \mathrm{H}_{2} \mathrm{O}\right)$ in acetone/water with the use of ultrasound irradiation [71]. The $\mathrm{Na}_{2} \mathrm{WO}_{4} \cdot 2 \mathrm{H}_{2} \mathrm{O}$ catalyst was the most efficient regarding the total yield of vanillin-based monomers (vanillin, acetovanillone, vanillic acid, and guaiacol) with a maximum yield of $0.51 \mathrm{wt} \%$ at $45{ }^{\circ} \mathrm{C}$ (Table 1, Entry 14). In addition, the use of ultrasound irradiation in this experiments results in high oxidative coupling of phenoxy radicals generated from LDP.

The metal/bromide catalyzed aerobic oxidation of alkylaromatic compounds in acetic acid solvent have shown to be a well-established method to produce aromatic carboxylic acids [88]. Thus, Partenheimer [72] investigated the aerobic oxidative solvolysis of lignin via $\mathrm{Co} / \mathrm{Mn} / \mathrm{Zr} / \mathrm{Br}$ catalysts in acetic acid-water solvent. After $2 \mathrm{~h}$ of reaction at $180{ }^{\circ} \mathrm{C}$ in the presence of $13.8 \mathrm{MPa}$ air, the highest yields of aromatic compounds with a total of $10.9 \mathrm{wt} \%$ could be obtained from organosolv lignin (Table 1, Entry 15).

In summary, most of these homogeneous systems lack selectivity for lignin, resulting in a relatively low yield of the target products. The separation and recyclability of homogeneous catalysts is still challenging for the catalytic oxidative solvolysis of lignin. Current research is focused on developing 
novel homogeneous catalysts and another kind of catalysts-heterogeneous catalysts-for the catalytic oxidative solvolysis of lignin.

\subsubsection{Heterogeneous Catalyst}

Considering the limitations of homogeneous catalytic oxidative solvolysis of lignin, heterogeneous catalytic systems have been developed with regard to their advantages in achieving a relatively high yield of the product, combined with an easy separation and recyclability of the catalyst. Microwave assisted catalytic oxidation of organosolv lignin over lanthanum modified SBA-15 catalyst was investigated [73]. The catalytic oxidation with $\mathrm{H}_{2} \mathrm{O}_{2}$ led to different yields of aldehydes, and the respective acids and aceto derivatives. The highest yield of vanillin was $9.94 \mathrm{wt} \%$ and that of syringaldehyde was $15.66 \mathrm{wt} \%$ (Table 1, Entry 16). Then, the oxidative solvolysis of organosolv lignin in methanol using $\mathrm{Pd} / \mathrm{CeO}_{2}$ catalyst was performed [74]. After $24 \mathrm{~h}$ of reaction at $185{ }^{\circ} \mathrm{C}$ under $\mathrm{O}_{2}$, several aromatic monomers including vanillin, guaiacol and 4-hydroxybenzaldehyde were identified and the yields of these monomers were 5.2, 0.87 and $2.4 \mathrm{wt} \%$, respectively (Table 1, Entry 17). After that, Deng et al. [75,76] synthesized the perovskite-type $\mathrm{LaMnO}_{3}$ and $\mathrm{LaCoO}_{3}$ catalysts for catalytic wet aerobic oxidation of lignin. Both the perovskite-type oxides, $\mathrm{LaMnO}_{3}$ and $\mathrm{LaCoO}_{3}$, were efficient and recyclable heterogeneous catalysts for catalytic oxidative solvolysis of lignin. When $\mathrm{LaMnO}_{3}$ was used, the lignin conversion was $57.0 \%$ after $3 \mathrm{~h}$ at $120^{\circ} \mathrm{C}$ in the presence of $0.5 \mathrm{MPa} \mathrm{O}_{2}$, and the maximum yields of vanillin, $p$-hydroxybenzyl aldehyde and syringaldehyde were 4.32 (30 $\mathrm{min}), 2.03$ (120 $\mathrm{min})$, and $9.33 \mathrm{wt} \%$ (30 $\mathrm{min}$ ) respectively (Table 1, Entry 18). When $\mathrm{LaCoO}_{3}$ was used, the lignin conversion after $3.0 \mathrm{~h}$ of reaction increased $46.7 \%$, and the maximum yield of vanillin, $p$-hydroxybenzyl aldehyde and syringaldehyde were 4.55 (60 $\mathrm{min}), 2.23(120 \mathrm{~min})$, and $9.99 \mathrm{wt} \%$ (50 $\mathrm{min}$ ) respectively (Table 1, Entry 19).

It can be concluded that both homogeneous and heterogeneous catalysts for the oxidative solvolysis of lignin should be further developed due to the low selectivity and production for specific compounds.

\subsection{Effects of Solvent System}

The oxidative solvolysis of lignin has been conducted with the help of molecular $\mathrm{O}_{2}$ or aqueous $\mathrm{H}_{2} \mathrm{O}_{2}$ as oxidants. The oxidation of raw lignin as well as lignin model compounds using molecular $\mathrm{O}_{2}$ or aqueous $\mathrm{H}_{2} \mathrm{O}_{2}$ as oxidants is highly promising. It was reported that the removal of $\mathrm{O}_{2}$ in the system of $\mathrm{H}_{2} \mathrm{O}_{2}$ as an oxidant had no effect on the oxidation reactions [83]. The in-situ oxygen produced by the decomposition of $\mathrm{H}_{2} \mathrm{O}_{2}$ during the reaction might be more reactive than the external oxygen.

Solvent molecules could coordinate or dissociate to the vacant metal coordination sites in homogeneous catalysis [89]. Different solvents in the oxidative solvolysis of lignin result in a significant change of the yields of aromatic products. Chan et al. [58] conducted the oxidative solvolysis of organosolv lignin into phenolic products in acetonitrile and ethyl acetate. Both acetonitrile and ethyl acetate were optimal solvents, whereas THF had to be added to contribute to the total miscibility of all the reaction components. Ma et al. [90] reported the selective oxidative $\mathrm{C}-\mathrm{C}$ bond cleavage of a lignin model compound over a vanadium catalyst in different solvents. In triethylamine, the $\mathrm{C}-\mathrm{H}$ bond cleavage was preferred over the vanadium-catalyzed oxidation with $\mathrm{O}_{2}$, while $\mathrm{C}-\mathrm{C}$ bond cleavage was dominant in acetic acid. It was believed that the coordination of the carboxylic group in acetic acid solvent to vanadium (V) catalyst was vital for $\mathrm{C}-\mathrm{C}$ bond cleavage.

The oxidative solvolysis of lignin generates a number of radicals resulting in the repolymerization reaction to limit the production of aromatic compounds. Therefore, some research explored the addition of some radical scavengers in order to quench the reactive lignin fragments before repolymerization took place. The alcohol as a quenching agent could generate the radicals such as $\mathrm{CH}_{3} \mathrm{O} \cdot$ or $\cdot \mathrm{CH}_{3}$. The role of those alcohols was investigated in the acidic degradation of lignin [68]. Methanol and ethanol might prevent the condensation through the competitive reaction with intermediate carbonium 
ions. Radical coupling of lignin fragments with $\mathrm{CH}_{3} \mathrm{O} \cdot$ and $\cdot \mathrm{CH}_{3}$ produced from methanol occurred via acid-catalyzed formation of dimethyl ether (Equations (1) and (2)).

$$
\begin{gathered}
2 \mathrm{CH}_{3} \mathrm{OH} \rightarrow \mathrm{CH}_{3} \mathrm{OCH}_{3}+\mathrm{H}_{2} \mathrm{O} \\
\mathrm{CH}_{3} \mathrm{OCH}_{3} \rightarrow \mathrm{CH}_{3} \mathrm{O} \cdot+\cdot \mathrm{CH}_{3} \mathrm{BDE}=84 \mathrm{kcal} \cdot \mathrm{mol}^{-1}
\end{gathered}
$$

The effect of varied alcohol solvents on the oxidative solvolysis of lignin is still uncertain. Pan et al. [91] found that acetonitrile and methanol exhibit a positive effect on the oxidative degradation of lignin, but dioxane and ethanol exhibit a negative effect. It was reported that a composite-solvent composed of water and an organic solvent could both promote depolymerization of lignin and prevent repolymerization of lignin fragments (monomers), increasing the yield of the aromatic products [66].

In addition, under specific reaction conditions the solvent will play a different role as opposed to its normal role. Deng et al. [74] proposed that methanol as a solvent in oxidative solvolysis of lignin model compounds, which could afford active $\mathrm{H}$ species for the hydrogenolysis of the $\beta-\mathrm{O}-4$ bond, producing phenol and acetophenone. Similarly, Shilpy et al. [92] investigated the influence of the property of the solvent on the oxidative solvolysis of vanillyl alcohol and vanillin. The highest conversion rate was observed in acetic acid (91\%), followed by ethyl alcohol $(70 \%)$, acetonitrile $(67 \%)$, $\mathrm{N}, \mathrm{N}$-dimethyl formaldehyde (35\%), tetrahydrofuran (20\%) and acetone (1\%). Thus it was proposed that the major role was played by peracetic acid that was in-situ generated by reacting acetic acid with $\mathrm{H}_{2} \mathrm{O}_{2}$ over an acid catalyst [93]. Then, peracetic acid accelerated and acted as an oxidant in the oxidation reaction.

Most of the solvents in the LDP process act as agents for dissolving lignin, products and homogeneous catalysts. In some cases, simple alcohols could exert an unexpected influence for protecting the produced aromatic fragments during the oxidative solvolysis process of lignin. The multi-function of solvents should be further investigated for the low-cost and high-efficient oxidative solvolysis of lignin.

\section{Oxidative Solvolysis of Lignin-Related Model Compounds}

The complexity and variability of lignin structure promoted the use of lignin-related model compounds for LDP studies, giving rise to a better understanding of the cracking mechanism via specific inter-unit linkage thus promoting the production of aromatic compounds. In this section, oxidative solvolysis of lignin-related model compounds (both aromatic monomers and oligomers) will be overviewed, concentrating on the reforming of aromatic monomers and the cracking of inter-unit linkages in oligomers.

\subsection{Oxidative Reforming of Lignin-Derived Monomers}

To understand the reactivity of the functional groups on lignin, much attention have been paid to the oxidative reforming of aromatic monomers. The representative lignin-related aromatic monomers such as apocynol, veratryl alcohol, 3-methoxy-4-hydroxybenzyl alcohol and 4-hydroxybenzyl alcohol were studied in recent years.

\subsubsection{Apocynol}

Sushanta et al. [94,95] reported an efficient oxidative solvolysis of apocynol (M1) over SBA-15 and $\mathrm{Co}$ (salen)/SBA-15 by using $\mathrm{H}_{2} \mathrm{O}_{2}$ as an oxidant. The reaction pathway for $M 1$ conversion on SBA-15 and Co (salen)/SBA-15 is shown in Figure 4. The first oxidation product was acetovanillone, then vanillin was formed through the side chain cleavage while 2-methoxybenzoquinone as a product of oxidation of the phenolic group together with oxidative degradation of the $p$-alkyl side chain. Co (salen)/SBA-15 showed a highly efficient performance (nearly $100 \%$ ) for $\mathbf{M 1}$ conversion after $40 \mathrm{~min}$ microwave heating and SBA- 15 showed an unusual oxidative ability and excellent selectivity for acetovanillone. Badamali et al. [96] also demonstrated the oxidation of $\mathbf{M 1}$ by mesoporous MCM-41, 
HMS, SBA-15 and amorphous silica with using $\mathrm{H}_{2} \mathrm{O}_{2}$ as an oxidant under microwave irradiation. With the same conversion pathway on SBA-15 or Co (salen)/SBA-15, acetovanillone, vanillin and 2-methoxybenzoquinone were the main products (Figure 4). Silica as a catalyst led to the highest conversion (94\%) of $M 1$ among the studied catalysts with the equal selectivity to acetovanillone and 2-methoxybenzoquinone. It could be concluded that the surface hydroxyl groups and internal pore structure of the employed silicas play a key role in the catalytic oxidative process. In addition, Hanson et al. [97] reported that dipicolinate vanadium complexes oxidized 2-phenoxyethanol in air. After the reaction at $100{ }^{\circ} \mathrm{C}$ for one week, approximately $20 \%$ of the 2-phenoxyethanol was consumed. Phenol (18\%), formic acid (6\%), and several other minor unidentified products were detected.

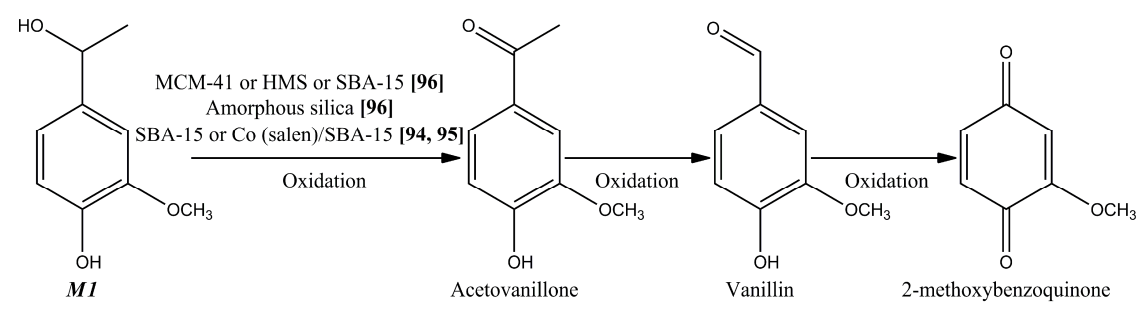

Figure 4. Reaction pathway for apocynol (M1) conversion on the catalysts.

\subsubsection{Veratryl Alcohol/3-Methoxy-4-Hydroxybenzyl Alcohol/4-Hydroxybenzyl Alcohol}

Mate et al. $[98,99]$ reported the oxidation of veratryl alcohol over a nano-structured, spinel $\mathrm{Co}_{3} \mathrm{O}_{4}$ catalyst in the presence of $\mathrm{O}_{2}$. After $7 \mathrm{~h}$ of reaction at $140{ }^{\circ} \mathrm{C}$ in water, the $\mathrm{Co}_{3} \mathrm{O}_{4}$ catalyst yielded the highest conversion of $85 \%$ together with a $96 \%$ selectivity to veratryl aldehyde. In different solvents, the catalytic activity of the $\mathrm{Co}_{3} \mathrm{O}_{4}$ catalyst was proved to occur in the following order: toluene $>$ water $>$ ethanol $>$ methanol. The highest conversion $(75 \%)$ was observed in a nonpolar solvent such as toluene together with above $97 \%$ selectivity to veratryl aldehyde. The proposed pathway for oxidation of veratryl alcohol over $\mathrm{Co}_{3} \mathrm{O}_{4}$ catalyst was presented in Scheme 1: The adsorbed veratryl alcohol formed an intermolecular bond between $\mathrm{Co}^{3+}$ and $\mathrm{O}_{2}$ while the surface oxide ion formed an intermolecular bond with the hydrogen of the alcoholic group; then the abstraction of hydrogen by the oxide ion lead to the formation of $\mathrm{Co}^{3+} \mathrm{OH}$ species; after that the activated $\mathrm{Co}^{3+} \mathrm{OH}$ species could produce another intermolecular hydrogen bond and abstraction of an electron resulted in the formation of $\mathrm{Co}^{2+}$, $\mathrm{H}_{2} \mathrm{O}$ and the main product, veratryl aldehyde; the reduced $\mathrm{Co}^{2+}$ species were reoxidized with $\mathrm{O}_{2}$ to regenerate the active $\mathrm{Co}^{3+} \mathrm{O}^{-}$species.

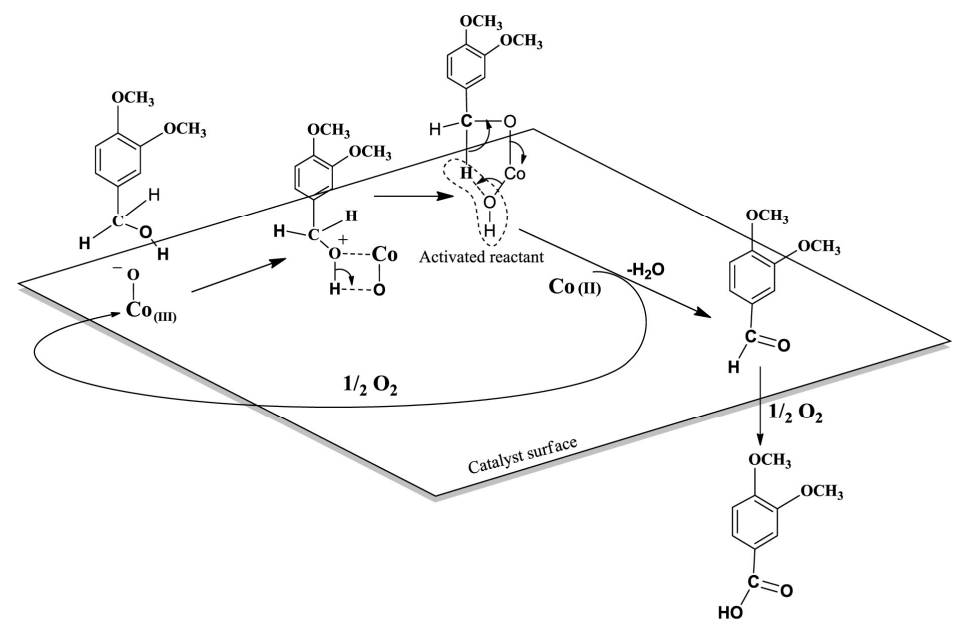

Scheme 1. Proposed pathways for oxidation of veratryl alcohol over $\mathrm{Co}_{3} \mathrm{O}_{4}$ catalyst [99], reproduced with permission from Elsevier. 
$\mathrm{Gu}$ et al. [100,101] performed the oxidation of a lignin model compound, 3-methoxy-4hydroxybenzyl alcohol (M2), over a mesoporous La/SBA-15 catalyst. Sixty-eight percent conversion of $M 2$ to vanillin was obtained after $30 \mathrm{~min}$ of reaction under $200 \mathrm{~W}$ microwave irradiation with the presence of $\mathrm{H}_{2} \mathrm{O}_{2}$ as oxidant. Reaction pathway for $M 2$ conversion on La/SBA-15 was shown in Figure 5. Pan et al. [91] also reported the microwave-assisted oxidative degradation of 3-methoxy-4-hydroxybenzyl alcohol (M2) and 4-hydroxybenzyl alcohol (M3) with 14 types of metal salts in the presence of $\mathrm{H}_{2} \mathrm{O}_{2}$. After $10 \mathrm{~min}$ of reaction with a $\mathrm{CrCl}_{3}$ catalyst at $80{ }^{\circ} \mathrm{C}$ in $\mathrm{H}_{2} \mathrm{O}$ /acetonitrile $(1: 1, v / v), M 2$ was converted to vanillin $(59.8 \%)$, vanillic acid $(9.7 \%)$, 5-hydroxyl-4-methoxyl-7-ketone-4-heptylic acid (17.0\%), etc., through the pathway depicted in Figure 5. Different from the conversion on La/SBA-15, vanillic acid underwent a ring-opening reaction to produce 5-hydroxyl-4-methoxyl-7-ketone-4-heptylic acid. Under the same reaction conditions, $M 3$ was converted to hydroquinone (33.2\%), 4-hydroxybenzaldehyde (22.2\%), 4-hydroxybenzonic acid $(7.6 \%)$, etc. The reaction pathway for $\mathrm{M3}$ conversion on $\mathrm{CrCl}_{3}$ was shown in Figure 6. 4-hydroxybenzaldehyde and 4-hydroxybenzonic acid were the first two oxidation products from M3. Then the decarboxylation of 4-hydroxybenzonic acid resulted in the formation of phenol and then phenol reacted with hydroxyl radicals formed by a microwave irradiation of $\mathrm{H}_{2} \mathrm{O}_{2}$, to produce hydroquinone. In addition, the pathway for $\mathbf{M} 2$ on immobilized MTO [63] and on $\mathrm{CoTiO}_{3}$ [92] was also different from the conversion on La/SBA-15 and on $\mathrm{CrCl}_{3}$ (Figure 5). After $6 \mathrm{~h}$ of reaction with immobilized MTO catalyst at room temperature in $\mathrm{CH}_{3} \mathrm{COOH} / \mathrm{H}_{2} \mathrm{O}_{2}, M 2$ was converted to vanillin (14.2\%), vanillic acid $(18.9 \%)$, muconolactone $(5.5 \%)$, etc. The muconolactone was mostly gained via an excessive oxidative ring opening reaction to a muconic acid intermediate followed by the formation of a lactone moiety, perhaps catalyzed by MTO. For the $\mathrm{CoTiO}_{3}$ catalyst, with the help of $\mathrm{H}_{2} \mathrm{O}_{2}$ in acetic acid and isopropanol solvent, a remarkable selectivity of $99.8 \%$ to vanillin was obtained at $85{ }^{\circ} \mathrm{C}$. The major products were vanillin, vanillic acid and guaiacol. Scheme 2 illustrated the proposed mechanism for the oxidation of vanillyl alcohol over $\mathrm{CoTiO}_{3}$ [92]. Initially the catalyst reacted with $\mathrm{H}_{2} \mathrm{O}_{2}$ to form a hydroperoxyl radical, which acts as a source of highly active oxidant, and then attacks the catalyst to form an intermediate. When vanillyl alcohol was activated on the catalyst surface, the electron-rich hydroperoxyl attacks the partially positive charged carbon and the hydrogen of the hydroxyl group through oxygen to form an activated oxygen species. This facilitated the removal of the hydroxyl group from the hydroperoxyl and produced water as a by-product. At the same time, the vanilloxy cation released a proton that was attacked by electron-rich oxygen of the hydroperoxyl group to produce the final product, vanillic acid.

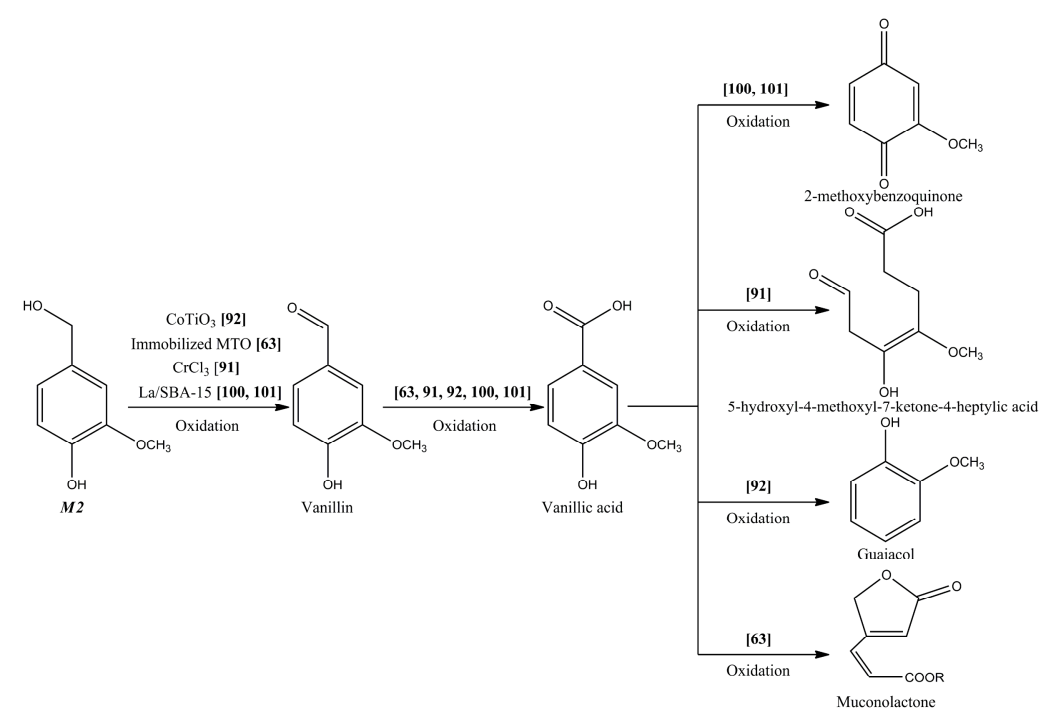

Figure 5. Reaction pathway for 3-methoxy-4-hydroxybenzyl alcohol (M2) conversion on the catalysts. 


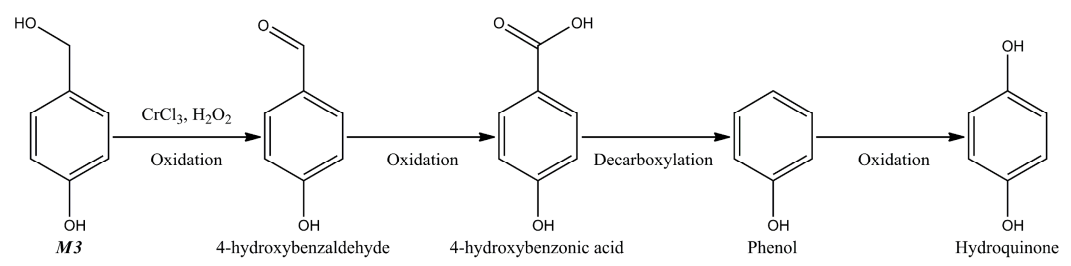

Figure 6. Reaction pathway for 4-hydroxybenzyl alcohol (M3) conversion on the catalyst [91], reproduced with permission from American Chemical Society.

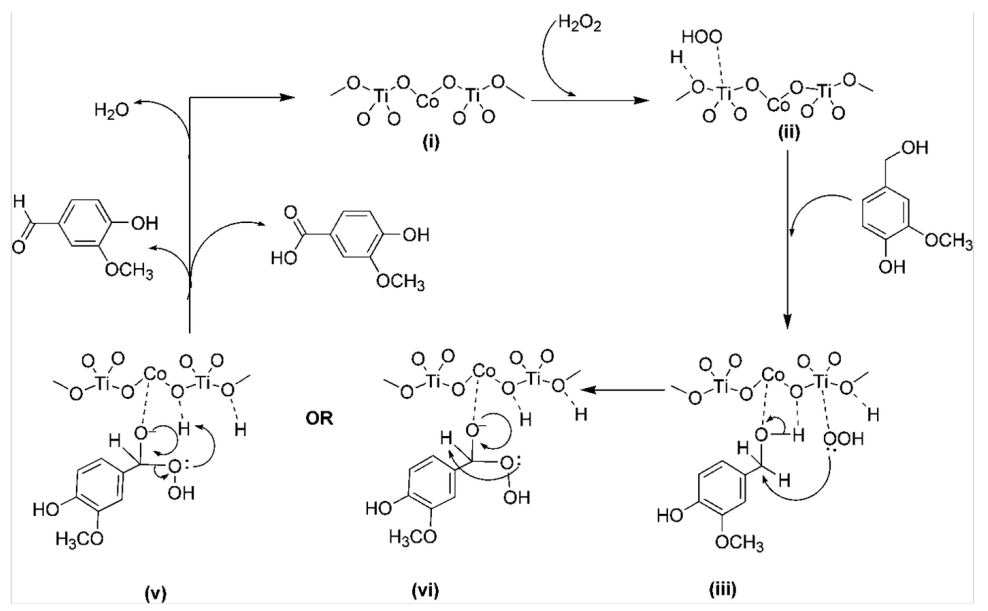

Scheme 2. The suggested mechanism for formation of the main oxidation product (vanillin and vanillic acid) from vanillyl alcohol in the presence of $\mathrm{CoTiO}_{3}$ [92], reproduced with permission from Royal Society of Chemistry.

\subsection{Oxidative Cracking of Typical Inter-Unit Linkages in Lignin-Derived Oligomers}

\subsubsection{C-C Linkage}

Homogeneous copper and vanadium complexes are well-known to be effective catalysts for aerobic oxidation reactions of diols with concomitant $C-C$ bond cleavage [102,103]. Recognizing that copper and vanadium complexes could potentially be used for the $\mathrm{C}-\mathrm{C}$ bond cleavage in lignin depolymerization, some scientists began to synthesize oxovanadium (e.g., Complex 1 in Figure 3) and copper catalysts and explore their fundamental reactivity. Hanson et al. [97,104] synthesized a series of vanadium complexes and homogeneous copper catalysts to explore their reactivity toward aerobic oxidation of a simple lignin model compound, 1,2-diphenyl-2-methoxyethanol (M4). The vanadium complex (dipic) $\mathrm{V}^{\mathrm{V}}(\mathrm{O})\left(\mathrm{O}^{i} \mathrm{Pr}\right)($ Complex 1$)$ reacted with $\boldsymbol{M 4}$ in $\mathrm{DMSO}$ with the addition of air at $100{ }^{\circ} \mathrm{C}$, producing predominantly benzaldehyde and methanol, but in pyridine it produced predominantly benzoic acid and methyl benzoate (Figure 7). The ketone benzoin methyl ether was an intermediate in this reaction. The $\mathrm{CuCl} / 2,2,6,6$-tetramethylpiperidine-1-oxyl radical (TEMPO) mixture could also react with $M 4$ in pyridine under $\mathrm{O}_{2}$ at $100{ }^{\circ} \mathrm{C}$, affording a mixture of benzaldehyde (84\%) and methyl benzoate (88\%) (Figure 7). Unlike the vanadium catalyst system, the copper-catalyzed reactions were proposed for direct $\mathrm{C}-\mathrm{C}$ bond cleavage of $\mathrm{M} 4$ without ketone or aldehyde intermediates. Recently, four new vanadium(V) complexes of amino-bis(phenolate) ligands (e.g., Complex 5 in Figure 3) have been synthesized, and all complexes were employed for the catalytic aerobic oxidative $\mathrm{C}-\mathrm{C}$ bond cleavage of $\mathbf{M} 4$ in air at $100{ }^{\circ} \mathrm{C}$, where benzaldehyde and methyl benzoate were identified as the major products [105]. In DMSO, a reaction with Complex 5 produced benzaldehyde at $90 \%$, methanol at $46 \%$, methyl benzoate at $36 \%$, benzoin methyl ether at $18 \%$, and a small amount of benzoic acid. In pyridine, methyl benzoate $(67 \%)$, benzoin methyl ether $(15 \%)$, and methanol $(2 \%)$ were obtained. Benzaldehyde was detected as a minor product $(1 \%)$ and no benzoic acid was detected. 


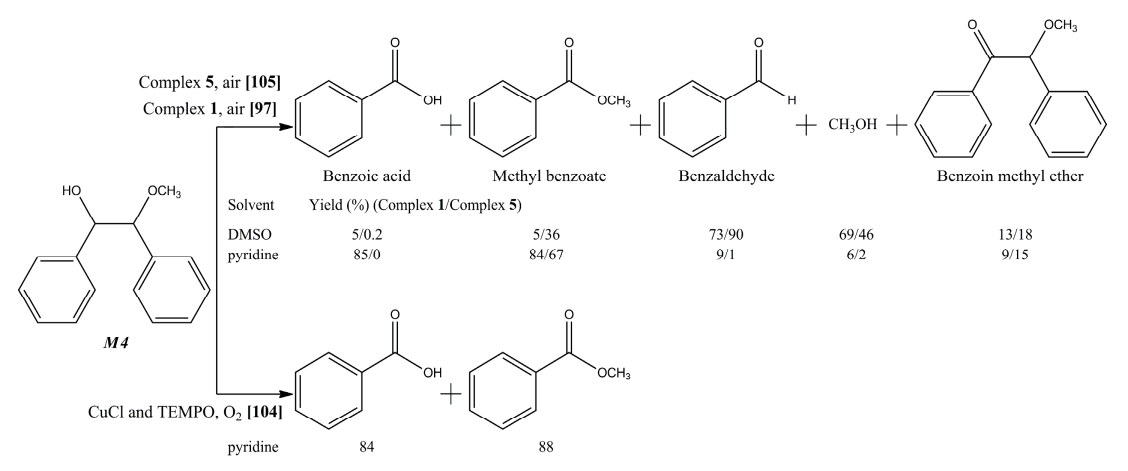

Figure 7. The aerobic oxidation of 1,2-diphenyl-2-methoxyethanol (M4) with vanadium and copper catalysts.

Degradation research indicated that $\beta-1$ structures are widespread, especially in hardwood lignin [106]. The $\beta-1$ linkage has not yet been adequately addressed by reductive cleavage. However, Hanson et al. $[47,104,107]$ successfully used their CuOTf/2,6-lutidine/TEMPO catalyst system and $(\mathrm{HQ})_{2} \mathrm{~V}^{\mathrm{V}}(\mathrm{O})\left(\mathrm{O}^{i} \mathrm{Pr}\right)($ Complex 2$)$ to achieve the aerobic oxidation of nonphenolic and phenolic $\beta-1$ lignin models (M5 and M6). It was found that the selectivity of the aerobic oxidation of $\beta-1$ lignin model compounds depended on both the catalyst and substrate. In the absence of phenolic groups, Complex 2 showed a high selectivity for $\mathrm{C}_{\alpha}-\mathrm{H}$ bond cleavage, however the copper catalyst system worked on $\mathrm{C}_{\alpha}-\mathrm{C}_{\beta}$ bond cleavage (Figure $8 \mathrm{a}$ ). The introduction of a phenolic functional group in the substrate enabled the cracking of the $C_{\alpha}-C_{\text {aryl }}$ bond with the help of both vanadium and copper catalysts (Figure $8 \mathrm{~b}$ ). As for the copper catalyst, the reaction of $\mathrm{C}-\mathrm{C}$ bond cleavage might proceed via either a one-electron oxidation or a selective oxidation of the primary alcohol, followed by a retro-aldol reaction, while, for the vanadium catalyst, the reaction was in accordance with a two-electron oxidation pathway $[47,104]$.
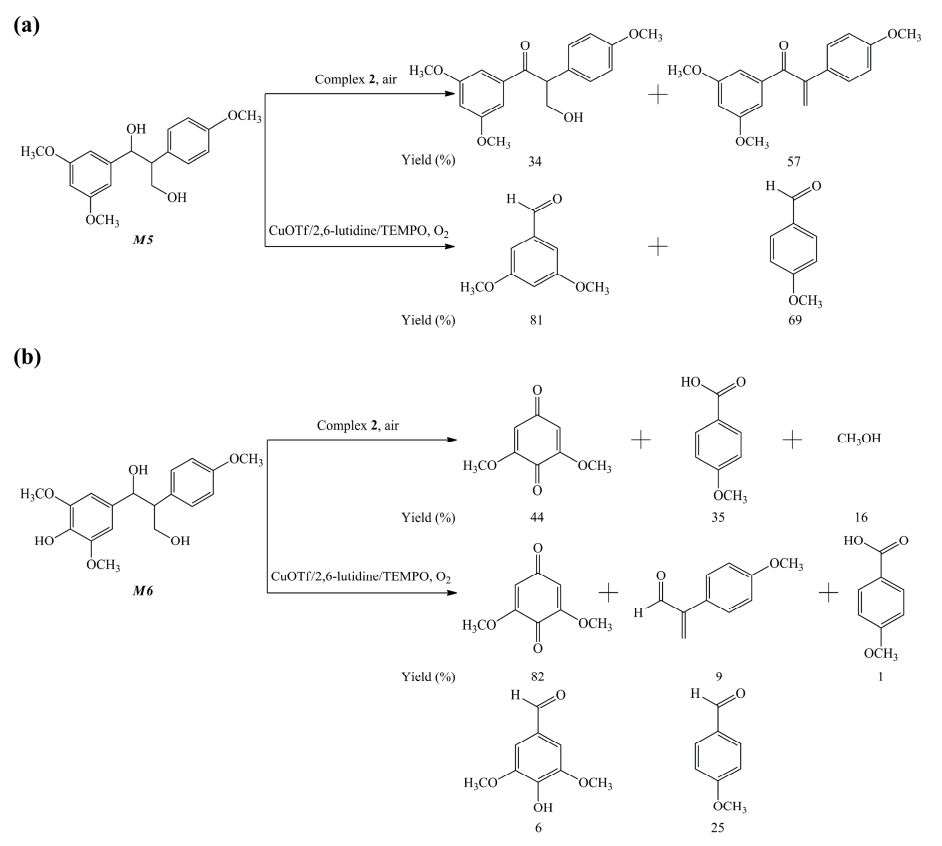

Figure 8. (a) The aerobic oxidation of non-phenolic $\beta-1$ linkage lignin model compound (M5) with vanadium and copper catalysts; and (b) the aerobic oxidation of phenolic $\beta-1$ linkage lignin model compound (M6) with vanadium and copper catalysts [104], reproduced with permission from American Chemical Society. 


\subsubsection{C-O Linkage}

The benzylic $\mathrm{C}-\mathrm{H}$ or $\mathrm{C}-\mathrm{OH}$ bonds in lignin would be easily attacked and transformed to carbonyl groups under oxidative conditions. Next, the $\mathrm{C}_{\alpha}-\mathrm{O}$ or $\mathrm{C}_{\beta}-\mathrm{O}$ bond can be cracked to the corresponding fragments [3]. The oxidation of $\alpha-\mathrm{O}-4$ or $\beta$-O- 4 linkages containing lignin model compounds has been extensively investigated. The key for achieving the production of specific chemicals from selective oxidation of lignin depends on the advance of catalysts.

\subsection{3. $\alpha-\mathrm{O}-4$ Containing Model Compound}

Haibach et al. [108] investigated the dehydroaryloxylation of aryl alkyl ethers in $p$-xylene using pincer iridium catalysts at a moderate temperature $\left(150\right.$ or $\left.200{ }^{\circ} \mathrm{C}\right)$. This system showed a rare atom-economical process for $\mathrm{C}-\mathrm{O}$ ether bond cleavage, producing a limited number of substituted alkyl aryl ethers. Recently, Gao et al. [64] used nitrogen-containing graphene material (LCN) as an effective catalyst for the oxidation of $\alpha$-O-4 types of a lignin model compound (M7) in the presence of tert-butyl hydroperoxide (TBHP), to produce aromatic aldehydes and acids in high yield. The reaction pathway for $M 7$ conversion on LCN is shown in Figure 9. A free-radical mechanism was involved, initiated by a benzylic $\mathrm{C}-\mathrm{H}$ bond activation, followed by a $\mathrm{C}_{\alpha}-\mathrm{O}$ bond cleavage, and finally completed by a further oxidation of intermediate aromatics. Similarly, an oxidative $\mathrm{C}-\mathrm{O}$ bond cleavage of $\boldsymbol{M} 7$ was demonstrated on Complex 5 at $80^{\circ} \mathrm{C}$, but the conversion was significantly limited [105].

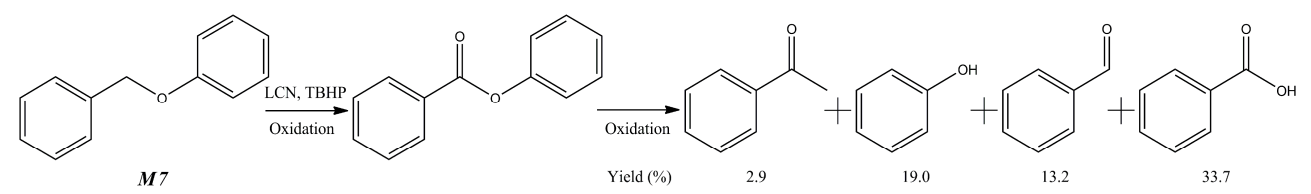

Figure 9. Reaction pathway for $\alpha-\mathrm{O}-4$ lignin model dimer (M7) conversion on the catalyst [64], reproduced with permission from John Wiley and Sons.

\subsection{4. $\beta$-O-4 Containing Model Compound}

The oxidative solvolysis of a lignin model compound, 2-phenoxy-1-phenylethanol (M8), was performed with a $\mathrm{CrCl}_{3}$ catalyst while using $\mathrm{H}_{2} \mathrm{O}_{2}$ as an oxidant at $80{ }^{\circ} \mathrm{C}$ [91]. After $10 \mathrm{~min}$ of reaction in $\mathrm{H}_{2} \mathrm{O}$ /acetonitrile solvent, $M 8$ was converted to phenol (3.1\%), benzoic acid $(7.4 \%)$, 2-hydroxy-1-phenylethanone $(17.3 \%), 2$-phenoxy-1-phenylethanone $(20.1 \%)$, etc. The reaction pathway for $M 8$ on $\mathrm{CrCl}_{3}$ is shown in Figure 10. M8 was firstly oxidized to produce 2-phenoxy-1-phenylethanone. The $\beta$-O-4 bond in 2-phenoxy-1-phenylethanone was cleaved through two pathways: (1) between the $\mathrm{C}_{\beta}-\mathrm{O}$ atoms with 2-hydroxy-1-phenylethanone and phenol as the major product; and (2) between the $C_{\alpha}-C_{\beta}$ atoms with benzoic acid as the major product. It is estimated that the cleavage of the $\mathrm{C}_{\beta}-\mathrm{O}$ bond was easier than that of the $\mathrm{C}_{\alpha}-\mathrm{C}_{\beta}$ bond. Hanson et al. [109] used the CuOTf/2,6-lutidine/TEMPO catalyst system to conduct the aerobic oxidation of $M 8$ obtaining the overall conversion of $67 \%$ after $40 \mathrm{~h}$ at $100{ }^{\circ} \mathrm{C}$. The major products were the formylated substrate 2-phenoxy-1-phenylformate, and the TEMPO-functionalized ketone 2-phenoxy-1-phenyl-2-(2,2,6,6-tetramethylpiperidin-1-yloxy)ethanone, while phenol, benzoic acid and 2-phenoxyacetophenone were produced only in small amounts. Recently, a new strategy for catalytic oxidation cleavage of aryl ethers in aralkyl aryl ethers involving a hemiacetal-like structure was proposed: $\mathrm{VO}(\mathrm{acac})_{2}$-catalyzed aerobic oxidation of $\mathbf{M} 8$ in the presence of acetic acid [90,110]. Benzaldehyde (5\%), benzoic acid (14\%), phenyl formate $(9 \%)$, phenol $(54 \%)$, 2-phenoxy-1-phenylethanone ( $2 \%)$ and some esterification products $(16 \%)$ were obtained after $8 \mathrm{~h}$ at $80{ }^{\circ} \mathrm{C}$. It was proposed that a cleavage of the linkage ( $\mathrm{C}-\mathrm{C}$ bond and $\mathrm{C}-\mathrm{O}$ bond) between the two aromatic rings could occur through at least two pathways: route A and a new route B (Figure 10). For route A, 2-phenoxy-1-phenylethanone was the intermediate that further cleaved to benzoic acid, phenyl formate and phenol. For route $B$, an initial oxidative activation of the $\mathrm{C}_{\beta}-\mathrm{H}$ bond produced a 
$\beta$-hydroxyl hemiacetal. Then, through a further cleavage of the $C-C$ bond, the following oxidative activation of the $\mathrm{C}_{\alpha}-\mathrm{H}$ bond, and the eventual cleavage of the $\mathrm{C}-\mathrm{O}$ bond can generate benzaldehyde, benzoic acid, phenyl formate and phenol.

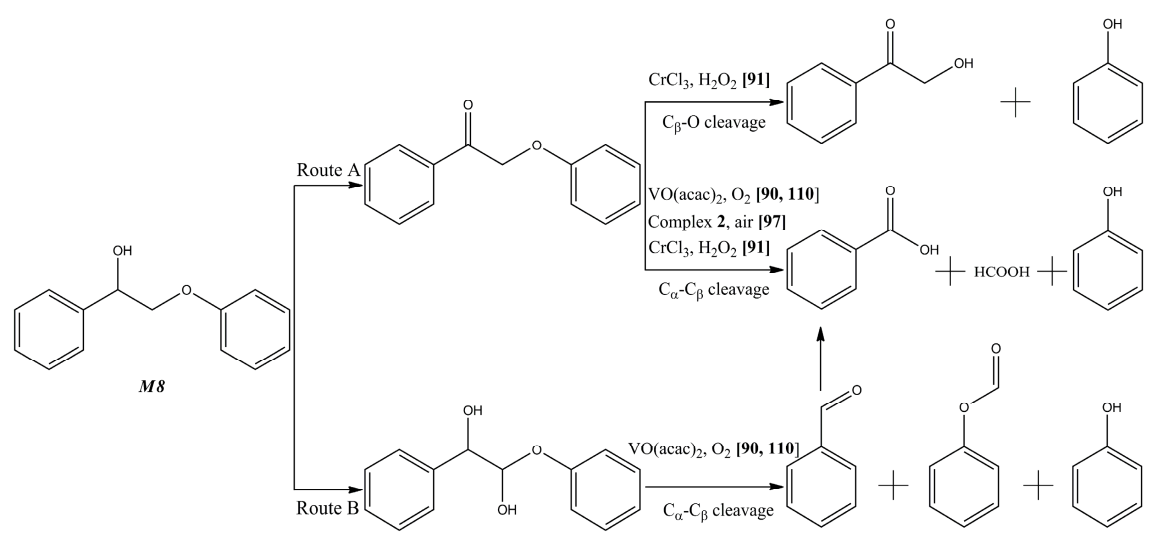

Figure 10. Reaction pathway for $\beta-\mathrm{O}-4$ lignin model dimer (M8) conversion on the catalysts.

The catalytic oxidative solvolysis of 1-(4-hydroxy-3-methoxyphenyl)-2-(2-methoxyphenoxy)propane-1,3-diol (M9) and 1-(3,4-dimethoxyphenyl)-2-(2-methoxyphenoxy)-propane-1,3-diol (M10) was performed over a 2:1 mixture of 1,10-phenanthroline and copper (II) sulfate pentahydrate in $\mathrm{NaOH}$ solution [67]. This reaction was conducted in the presence of $\mathrm{O}_{2}$ in methanol at $80{ }^{\circ} \mathrm{C}$. Vanillin was the major identified product from $M 9$ while veratric acid was the major product from $M 10$ (Figure 11). The $\beta-\mathrm{O}-4$ bond was cleaved mainly between the $\mathrm{C}_{\alpha}-\mathrm{C}_{\beta}$ atoms and different mechanisms were proposed because of the phenolic hydroxyl group para to the side chain. Blandez et al. [111] found that graphene oxide promoted the oxidative degradation of $\mathbf{M 9}$ mainly to guaiacol, 2-methoxyquinone, vanillic acid and coniferyl aldehyde. After $24 \mathrm{~h}$ of reaction at $140{ }^{\circ} \mathrm{C}$ in acetonitrile solvent in the presence of $\mathrm{O}_{2}, M 9$ was converted to coniferyl aldehyde (20\%), vanillic acid (2\%), vanillin (6\%), 2-methoxyquinone (5\%) and guaiacol (96\%). Reaction pathway for M9 on graphene oxide was shown in Figure 11. \{Fe-DABCO oxidative cleavage of M10 with peroxides in DMSO was also reported [60]. Guaiacol and veratraldehyde with $42 \%$ and $35 \%$ yield were obtained as the major products at $100{ }^{\circ} \mathrm{C}$ after $16 \mathrm{~h}$. The reaction pathway for $\mathbf{M 1 0}$ on $\{\mathrm{Fe}-\mathrm{DABCO}\}$ is shown in Figure 11. Transition-metal-containing hydrotalcites $(\mathrm{HTc})$ and $\mathrm{V}(\mathrm{acac})_{3} / \mathrm{Cu}\left(\mathrm{NO}_{3}\right)_{2} \cdot 3 \mathrm{H}_{2} \mathrm{O}$ mixtures were employed for the catalytic cleavage of $\mathbf{M 1 0}$ with $\mathrm{O}_{2}$ as an oxidant [62]. After $16 \mathrm{~h}$ of reaction at $135^{\circ} \mathrm{C}$ in pyridine solvent in the presence of $\mathrm{O}_{2}, \mathbf{M 1 0}$ was mainly converted to veratraldehyde ( $\left.38 \%\right)$, veratric acid (31\%) and phenol. The reaction pathway for M10 on HTc is shown in Figure 11.

A ligand is an ion or molecule (functional group) linked to a central metal atom to structure a coordination complex. Compared to other ligands, salen complexes are relatively stable, inexpensive and can be readily synthesized. A series of vanadium (V) complexes (e.g., Complex 3 in Figure 3) bearing a Schiff base ligand for the non-oxidative solvolysis of a lignin model compound (M11) was demonstrated at $80{ }^{\circ} \mathrm{C}$ [112]. Different from the conversion pathway on copper complex, the $\beta-\mathrm{O}-4$ bond was cleaved mainly at the $\mathrm{C}_{\beta}-\mathrm{O}$ bond (Figure 11). Thus M11 was converted to alkene, 2-methoxyphenol and ketone after $24 \mathrm{~h}$ of reaction in $\mathrm{CD}_{3} \mathrm{CN}$ solvent. Another series of dipicolinate vanadium (V) complexes (e.g., Complex 2 in Figure 3) for the oxidative degradation of 1-phenyl-2-phenoxyethanol (M8) was studied at $100{ }^{\circ} \mathrm{C}$ in air [97]. Differently, M8 was mainly converted to formic acid, benzoic acid, phenol, and 2-phenoxyacetophenone (Figure 10). Ruthenium-triphos complexes also exhibited an outstanding catalytic activity and selectivity in the redox-neutral $\mathrm{C}-\mathrm{C}$ bond cleavage of $\mathrm{M10}$ [113]. The use of $\mathrm{Ru}(\mathrm{CO})(\mathrm{Cl})(\mathrm{H})-($ triphos) [114] resulted in the products from the $C_{\alpha}-C_{\beta}$ bond cleavage in $66 \%$ yield, whereas the products from the $C_{\beta}-O$ bond cleavage were formed in $4 \%$ yield at $160{ }^{\circ} \mathrm{C}$ after $4 \mathrm{~h}$ of reaction (Figure 11). It should be noted that the 
phenolic group played an important role: (1) $\mathrm{C}_{\alpha}-\mathrm{OH}$ was required for both the $\mathrm{C}_{\alpha}-\mathrm{C}_{\beta}$ and the $\mathrm{C}_{\beta}-\mathrm{O}$ bond cleavage; and (2) $\mathrm{C}_{\gamma}-\mathrm{OH}$ was essential for accessing to the $\mathrm{C}_{\alpha}-\mathrm{C}_{\beta}$ bond cleavage.

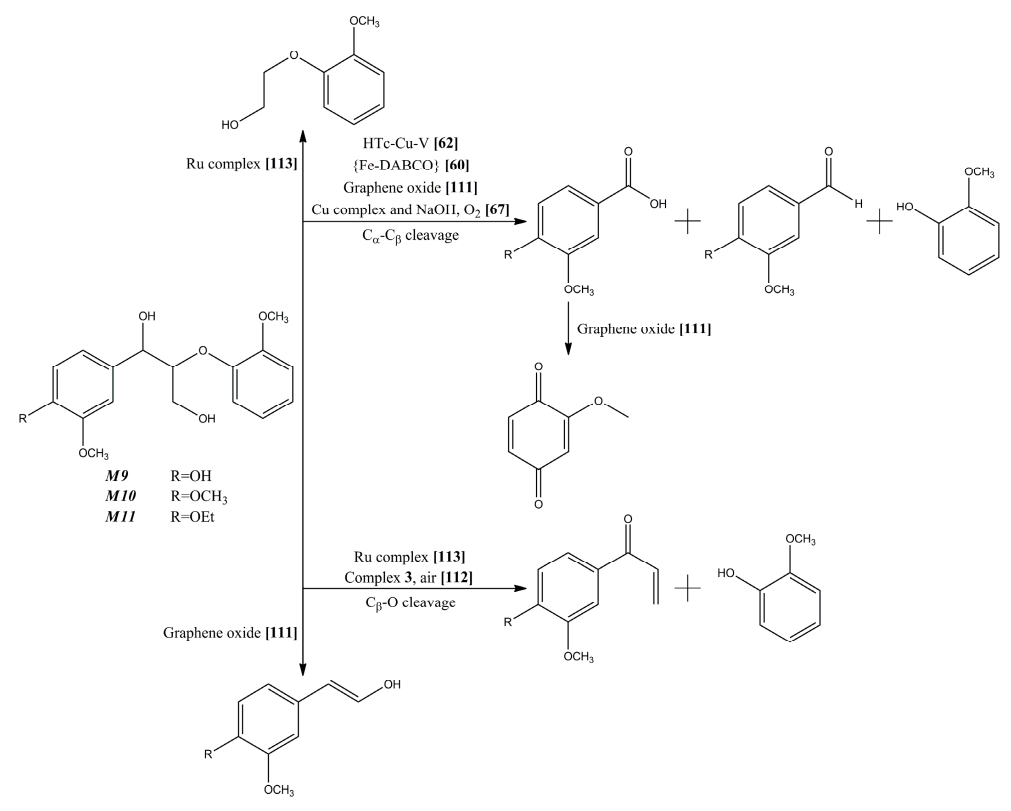

Figure 11. Reaction pathway for $\beta-\mathrm{O}-4$ lignin model dimer (M9, M10, and M11) conversion on the catalysts.

To compare the differences in selectivity of products between Complex 2 and Complex 3 , the aerobic oxidation of a lignin model compound (M13) reacting with Complex 2 and Complex 3 was investigated [115]. Complex 3 afforded the production of alkene, 2-methoxyphenol and ketone from $\mathrm{C}_{\beta}-\mathrm{O}$ bond cleavage, while Complex 2 gave the production of 2,6-dimethoxybenzoquinone and acrolein derivative, and ketone from a $\mathrm{C}_{\alpha}-\mathrm{C}_{\text {aryl }}$ bond cleavage (Figure 12). An application of an isotope tracer technique showed that Complex 3 broke the $\mathrm{C}-\mathrm{O}$ bond in the model compound via cracking of the benzylic $\mathrm{C}_{\alpha}-\mathrm{H}$ bond, while Complex 2 broke the $\mathrm{C}_{\alpha}-\mathrm{C}_{\text {aryl }}$ bond without cleavage of the benzylic $\mathrm{C}_{\alpha}-\mathrm{H}$ bond. Further experiments showed that no $\mathrm{C}_{\alpha}-\mathrm{C}_{\text {aryl }}$ bond cleavage was observed in the aerobic oxidation of a non-phenolic model compound (M12) with Complex 2. It was consistent with the result of aerobic oxidation of a $\beta-1$ linkage lignin model compound on Complex 2 (Figure 8). Mechanisms of Complex 2 and Complex 3 catalyses during reactions were proposed in a recent publication [116]. Parker et al. [117] attempted to determine the effect of ligand structure on the activity of vanadium Schiff-base catalysts (e.g., Complex 3) towards the degradation of $\beta-\mathrm{O}-4$ contained dimers. Ortho-bulky, electron-donating ligand substituents were determined to make the most active catalyst, which can be enhanced by the addition of bulky aliphatic substituents such as tert-butyl and adamantyl groups. The trityl-substituted complex was not that active due to the enhanced steric hindrance, confining the substrate access to the active sites of catalyst [117].

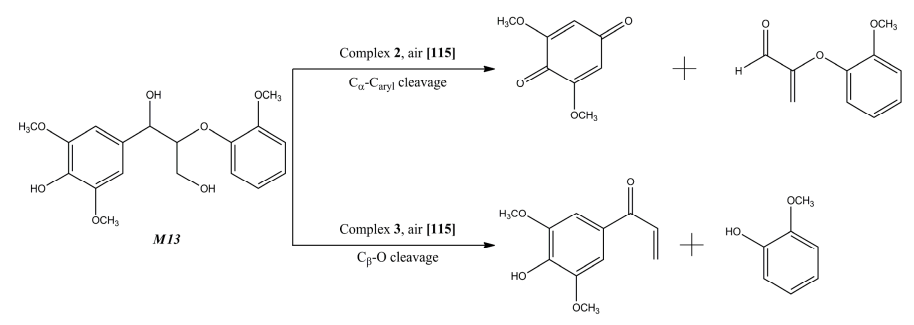

Figure 12. Reaction pathway for $\beta-\mathrm{O}-4$ lignin model dimer (M13) conversion on the catalysts. 
The oxidation of lignin-related model compounds, 2-phenoxy-1-phenylethanol (M8) and 2-(4-methoxyphenoxy)-1-phenylethanol (M14), on a $\mathrm{Pd} / \mathrm{CeO}_{2}$ catalyst was performed in methanol under $\mathrm{O}_{2}$ [74]. The reaction mechanism for the conversion of $M 8$ over $\mathrm{Pd} / \mathrm{CeO}_{2}$ in methanol with the presence of $\mathrm{O}_{2}$ is shown in Scheme 3. The $\mathrm{C}_{\alpha}-\mathrm{OH}$ of 2-phenoxy-1-phenylethanol was first oxidized due to the catalytic function of $\mathrm{Pd}$ nanoparticles, to form 2-phenoxy-1-phenylethanone, whose $\beta-\mathrm{O}-4$ bond became weakened due to the presence of $\mathrm{C}_{\alpha}=\mathrm{O}$. The subsequent hydrogenolysis of the $\beta-\mathrm{O}-4$ bond of 2-phenoxy-1-phenylethanone resulted in the form of acetophenone and phenol over the $\mathrm{Pd} / \mathrm{CeO}_{2}$ catalyst. On the other hand, the oxidative cracking of the $\beta-\mathrm{O}-4$ bond over $\mathrm{CeO}_{2}$ might lead to the formation of phenol and an oxidized intermediate (e.g., 2-hydroxyacetophenone). Meanwhile, a small amount of acetophenone can be produced during this process. Finally, the oxidized intermediate experienced the $\mathrm{C}-\mathrm{C}$ bond cracking, producing benzoic acid and methyl benzoate. Phenol, acetophenone and methyl benzoate were produced with the yield of $48 \%, 38 \%$ and $14 \%$ from the oxidation of $M 8$, while 4-methoxyphenol, acetophenone and methyl benzoate were produced with yields of $82 \%, 38 \%$ and $40 \%$ from the oxidation of $\mathbf{M 1 4}$ at $185{ }^{\circ} \mathrm{C}$ for $24 \mathrm{~h}$. It could be concluded that ortho-methoxy substituents further elevated the performance of the $\mathrm{Pd} / \mathrm{CeO}_{2}$ catalyst, which was consistent with the other report stating that ortho-methoxy substituents could weaken the stability of the aromatic ring, promoting its over-oxidation [64].

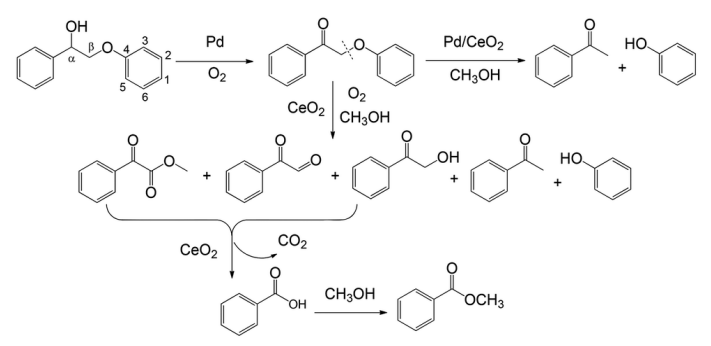

Scheme 3. Proposed pathway for oxidative conversion of 2-phenoxy-1-phenylethanol (M8) over a $\mathrm{Pd} / \mathrm{CeO}_{2}$ catalyst [74], reproduced with permission from Royal Society of Chemistry.

Moreover, Wang et al. [118] reported a two-step strategy for lignin C-C bond conversion via a $\beta-\mathrm{O}-4$ alcohol oxidation to ketone over the $\mathrm{VOSO}_{4} / \mathrm{TEMPO}[(2,2,6,6$-tetramethylpiperidin-1-yl)oxyl)] catalyst, followed by a ketone oxidation over $\mathrm{Cu}(\mathrm{OAc})_{2} / 1,10$-phenanthroline catalyst to acids and phenols. The proposed reaction mechanism is shown in Scheme 4 . The oxidation of a $\mathrm{C}_{\alpha}-\mathrm{OH}$ alcohol to a ketone activated the $\mathrm{C}_{\beta}-\mathrm{H}$ bond. The $\mathrm{Cu}(\mathrm{OAc})_{2} / 1,10$-phenanthroline reacted with oxygen to form a copper-oxo-bridged dimer. The activation of the $\mathrm{C}_{\alpha}-\mathrm{C}_{\beta}$ bond in the form of a hydroxyl ketone structure-like intermediate significantly decreased its bond energy, resulting in the formation of benzoic acid and phenyl formate. Transfer of a hydroxyl group generated benzoic acid, restoring the initial copper complex. Finally, the oxidative decarboxylation of phenyl formate generated phenol and $\mathrm{CO}_{2}$.

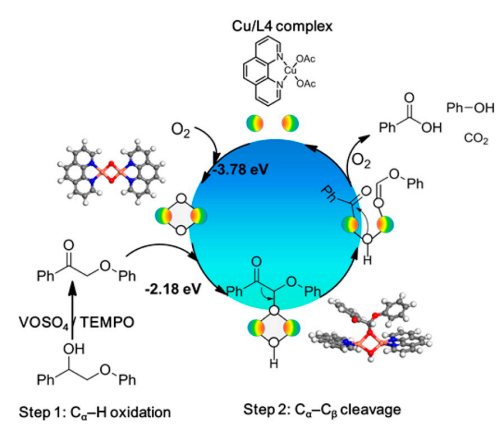

Scheme 4. Proposed reaction mechanism for two-step, catalytic C-C bond oxidative cleavage process [118], reproduced with permission from American Chemical Society. 
The oxidative solvolysis of lignin-related model compounds with homogeneous catalysts was mostly reported for enhancing the production of aromatic aldehydes, aromatic ketones, benzoquinones, carboxylic acids, etc. The oxidative solvolysis of model compounds with heterogeneous catalysts may achieve a high selectivity of specific products. However, the performance of both homogeneous and heterogeneous catalysts in the cleavage of inter-unit linkages is still ambiguous in the oxidative solvent system, confining the understanding of inherent mechanism of whole lignin depolymerization process.

\section{Summary and Outlook}

The catalytic oxidation of lignin in solvent systems is attracting more and more attention for producing renewable aromatic chemicals. A number of functionalized monomeric products were obtained from oxidative depolymerization of lignin, including vanillin, vanillic acid, syringaldehyde and syringic acid. Considering the ambiguities in the inherent mechanism of (catalytic) oxidative solvolysis of lignin process and the limited selectivity and yield of renewable chemicals, several issues should be addressed: (1) identification of the oligomer structure for specifying the inherent oxidative depolymerization mechanism of natural lignin; (2) design of highly efficient catalyst for $\mathrm{C}-\mathrm{C}$ type inter-unit linkages; (3) strategies for suppressing the repolymerization of the produced fragments; (4) low-cost separation and purification technology of the specific aromatic compounds from an LDP system; and (5) stability of the heterogeneous catalysts during LDP and its reactivation.

Acknowledgments: The authors greatly acknowledge the funding support from the projects supported by National Natural Science Foundation of China (Grant Nos. 51676034 and 51628601) and Natural Science Foundation of Jiangsu Province (project reference: BK20161423).

Conflicts of Interest: The authors declare no conflict of interest.

\section{References}

1. Li, C.; Zhao, X.; Wang, A.; Huber, G.W.; Zhang, T. Catalytic transformation of lignin for the production of chemicals and fuels. Chem. Rev. 2015, 115, 11559-11624. [CrossRef] [PubMed]

2. Sawin, J.L.; Sverrisson, F. Renewables 2014: Global Status Report; REN21 Secretariat: Paris, France, 2014; p. 214.

3. Lange, H.; Decina, S.; Crestini, C. Oxidative upgrade of lignin-Recent routes reviewed. Eur. Polym. J. 2013, 49, 1151-1173. [CrossRef]

4. Huber, G.W.; Iborra, S.; Corma, A. Synthesis of transportation fuels from biomass: Chemistry, catalysts, and engineering. Chem. Rev. 2006, 106, 4044-4098. [CrossRef] [PubMed]

5. Melero, J.A.; Iglesias, J.; Garcia, A. Biomass as renewable feedstock in standard refinery units. Feasibility, opportunities and challenges. Energy Environ. Sci. 2012, 5, 7393-7420. [CrossRef]

6. Gallezot, P. Conversion of biomass to selected chemical products. Chem. Soc. Rev. 2012, 41, 1538-1558. [CrossRef] [PubMed]

7. Tuck, C.O.; Perez, E.; Horvath, I.T.; Sheldon, R.A.; Poliakoff, M. Valorization of biomass: Deriving more value from waste. Science 2012, 337, 695-699. [CrossRef] [PubMed]

8. Besson, M.; Gallezot, P.; Pinel, C. Conversion of biomass into chemicals over metal catalysts. Chem. Rev. 2014, 114, 1827-1870. [CrossRef] [PubMed]

9. Mamman, A.S.; Lee, J.-M.; Kim, Y.-C.; Hwang, I.T.; Park, N.-J.; Hwang, Y.K.; Chang, J.-S.; Hwang, J.-S. Furfural: Hemicellulose/xylose derived biochemical. Biofuels Bioprod. Biorefin. 2008, 2, 438-454. [CrossRef]

10. Doherty, W.O.S.; Mousavioun, P.; Fellows, C.M. Value-adding to cellulosic ethanol: Lignin polymers. Ind. Crops Prod. 2011, 33, 259-276. [CrossRef]

11. Serrano-Ruiz, J.C.; Luque, R.; Sepúlveda-Escribanoa, A. Transformations of biomass-derived platform molecules: From high added-value chemicals to fuelsvia aqueous-phase processing. Chem. Soc. Rev. 2011, 40, 5266-5281. [CrossRef] [PubMed]

12. Rinaldi, R.; Palkovits, R.; Schüth, F. Depolymerization of cellulose using solid catalysts in ionic liquids. Angew. Chem. Int. Ed. 2008, 47, 8047-8050. [CrossRef] [PubMed]

13. Gosselink, R.J.A.; de Jong, E.; Guran, B.; Abächerli, A. Co-ordination network for lignin-standardisation, production and applications adapted to market requirements. Ind. Crops Prod. 2004, 20, 121-129. [CrossRef] 
14. Calvo-Flores, F.G.; Dobado, J.A. Lignin as renewable raw material. ChemSusChem 2010, 3, 1227-1235. [CrossRef] [PubMed]

15. Ragauskas, A.J.; Beckham, G.T.; Biddy, M.J.; Chandra, R.; Chen, F.; Davis, M.F.; Davison, B.H.; Dixon, R.A.; Gilna, P.; Keller, M.; et al. Lignin valorization: Improving lignin processing in the biorefinery. Science 2014, 344, 709-721. [CrossRef] [PubMed]

16. Naik, S.N.; Goud, V.V.; Rout, P.K.; Dalai, A.K. Production of first and second generation biofuels: A comprehensive review. Renew. Sustain. Energy Rev. 2010, 14, 578-597. [CrossRef]

17. Hu, L.H.; Pan, H.; Zhou, Y.H.; Zhang, M. Methods to improve lignin's reactivity as a phenol substitute and as replacement for other phenolic compounds: A brief review. BioResources 2011, 6, 3515-3525.

18. Deuss, P.J.; Barta, K. From models to lignin: Transition metal catalysis for selective bond cleavage reactions. Coord. Chem. Rev. 2016, 306, 510-532. [CrossRef]

19. Kang, S.; Li, X.; Fan, J.; Chang, J. Hydrothermal conversion of lignin: A review. Renew. Sustain. Energy Rev. 2013, 27, 546-558. [CrossRef]

20. Carpenter, D.; Westover, T.L.; Czernik, S.; Jablonski, W. Biomass feedstocks for renewable fuel production: A review of the impacts of feedstock and pretreatment on the yield and product distribution of fast pyrolysis bio-oils and vapors. Green Chem. 2014, 16, 384-406. [CrossRef]

21. Shen, D.; Xiao, R.; Gu, S.; Luo, K. The pyrolytic behavior of cellulose in lignocellulosic biomass: A review. RSC Adv. 2011, 1, 1641-1660. [CrossRef]

22. Azadi, P.; Inderwildi, O.R.; Farnood, R.; King, D.A. Liquid fuels, hydrogen and chemicals from lignin: A critical review. Renew. Sustain. Energy Rev. 2013, 21, 506-523. [CrossRef]

23. Shen, D.; Jin, W.; Hu, J.; Xiao, R.; Luo, K. An overview on fast pyrolysis of the main constituents in lignocellulosic biomass to valued-added chemicals: Structures, pathways and interactions. Renew. Sustain. Energy Rev. 2015, 51, 761-774. [CrossRef]

24. Chatel, G.; Rogers, R.D. Review: Oxidation of lignin using ionic liquids-An innovative strategy to produce renewable chemicals. ACS Sustain. Chem. Eng. 2014, 2, 322-339. [CrossRef]

25. Behling, R.; Valange, S.; Chatel, G. Heterogeneous catalytic oxidation for lignin valorization into valuable chemicals: What results? What limitations? What trends? Green Chem. 2016, 18, 1839-1854. [CrossRef]

26. Yokoyama, T. Revisiting the mechanism of $\beta-\mathrm{O}-4$ bond cleavage during acidolysis of lignin. Part 6: A review. J. Wood Chem. Technol. 2014, 35, 27-42. [CrossRef]

27. Mota, M.I.F.; Rodrigues Pinto, P.C.; Loureiro, J.M.; Rodrigues, A.E. Recovery of vanillin and syringaldehyde from lignin oxidation: A review of separation and purification processes. Sep. Purif. Technol. 2015, 45, 227-259. [CrossRef]

28. Xu, C.; Arancon, R.A.D.; Labidid, J.; Luque, R. Lignin depolymerisation strategies-Towards valuable chemicals and fuels. Chem. Soc. Rev. 2014, 43, 7485-7500. [CrossRef] [PubMed]

29. Deuss, P.J.; Barta, K.; de Vries, J.G. Homogeneous catalysis for the conversion of biomass and biomass-derived platform chemicals. Catal. Sci. Technol. 2014, 4, 1174-1196. [CrossRef]

30. Zakzeski, J.; Bruijnincx, P.C.A.; Jongerius, A.L.; Weckhuysen, B.M. The catalytic valorization of lignin for the production of renewable chemicals. Chem. Rev. 2010, 110, 3552-3599. [CrossRef] [PubMed]

31. Collinson, S.R.; Thielemans, W. The catalytic oxidation of biomass to new materials focusing on starch, cellulose and lignin. Coord. Chem. Rev. 2010, 254, 1854-1870. [CrossRef]

32. Dai, J.; Patti, A.F.; Saito, K. Recent developments in chemical degradation of lignin: Catalytic oxidation and ionic liquids. Tetrahedron Lett. 2016, 57, 4945-4951. [CrossRef]

33. Ma, R.; Xu, Y.; Zhang, X. Catalytic oxidation of biorefinery lignin to value-added chemicals to support sustainable biofuel production. ChemSusChem 2015, 8, 24-51. [CrossRef] [PubMed]

34. Gupta, K.C.; Kumar Sutar, A.; Lin, C.-C. Polymer-supported schiff base complexes in oxidation reactions. Coord. Chem. Rev. 2009, 253, 1926-1946. [CrossRef]

35. Amadio, E.; Di Lorenzo, R.; Zonta, C.; Licini, G. Vanadium catalyzed aerobic carbon-carbon cleavage. Coord. Chem. Rev. 2015, 301-302, 147-162. [CrossRef]

36. Stewart, D. Lignin as a base material for materials applications: Chemistry, application and economics. Ind. Crops Prod. 2008, 27, 202-207. [CrossRef]

37. Crestini, C.; Crucianelli, M.; Orlandi, M.; Saladino, R. Oxidative strategies in lignin chemistry: A new environmental friendly approach for the functionalisation of lignin and lignocellulosic fibers. Catal. Today 2010, 156, 8-22. [CrossRef] 
38. Dong, C.; Feng, C.; Liu, Q.; Shen, D.; Xiao, R. Mechanism on microwave-assisted acidic solvolysis of black-liquor lignin. Bioresour. Technol. 2014, 162, 136-141. [CrossRef] [PubMed]

39. Shen, D.; Liu, N.; Dong, C.; Xiao, R.; Gu, S. Catalytic solvolysis of lignin with the modified husys in formic acid assisted by microwave heating. Chem. Eng. J. 2015, 270, 641-647. [CrossRef]

40. Nimz, H. Beech lignin-Proposal of a constitutional scheme. Angew. Chem. Int. Ed. 1974, 13, $313-321$. [CrossRef]

41. Erickson, M.; Larsson, S.; Miksche, G.E. Analysis using gas-chromatography of lignin oxidation-products. 8. Structure of spruce lignin. Acta Chem. Scand. 1973, 27, 903-914. [CrossRef]

42. Hage, R.; Lienke, A. Applications of transition-metal catalysts to textile and wood-pulp bleaching. Angew. Chem. Int. Ed. 2006, 45, 206-222. [CrossRef] [PubMed]

43. Hu, J.; Xiao, R.; Shen, D.; Zhang, H. Structural analysis of lignin residue from black liquor and its thermal performance in thermogravimetric-fourier transform infrared spectroscopy. Bioresour. Technol. 2013, 128, 633-639. [CrossRef] [PubMed]

44. Shen, D.; Cheng, C.; Liu, N.; Xiao, R. Lignin depolymerization (LDP) with solvolysis for selective production of renewable aromatic chemicals. In Production of Biofuels and Chemicals from Lignin; Fang, Z., Smith, R.L., Jr., Eds.; Springer: Berlin, Germany, 2016; p. 290.

45. Choi, Y.S.; Singh, R.; Zhang, J.; Balasubramanian, G.; Sturgeon, M.R.; Katahira, R.; Chupka, G.; Beckham, G.T.; Shanks, B.H. Pyrolysis reaction networks for lignin model compounds: Unraveling thermal deconstruction of $\beta-\mathrm{O}-4$ and $\alpha-\mathrm{O}-4$ compounds. Green Chem. 2016, 18, 1762-1773. [CrossRef]

46. Forsythe, W.G.; Garrett, M.D.; Hardacre, C.; Nieuwenhuyzen, M.; Sheldrake, G.N. An efficient and flexible synthesis of model lignin oligomers. Green Chem. 2013, 15, 3031-3038. [CrossRef]

47. Sedai, B.; Díaz-Urrutia, C.; Baker, R.T.; Wu, R.; Silks, L.A.P.; Hanson, S.K. Aerobic oxidation of $\beta-1$ lignin model compounds with copper and oxovanadium catalysts. ACS Catal. 2013, 3, 3111-3122. [CrossRef]

48. Reddy, G.V.B.; Sridhar, M.; Gold, M.H. Cleavage of nonphenolic $\beta-1$ diarylpropane lignin model dimers by manganese peroxidase from phanerochaete chrysosporium. Evidence for a hydrogen abstraction mechanism. Eur. J. Biochem. 2003, 270, 284-292. [CrossRef] [PubMed]

49. Tran, F.; Lancefield, C.S.; Kamer, P.C.J.; Lebl, T.; Westwood, N.J. Selective modification of the $\beta$ - $\beta$ linkage in DDQ-treated kraft lignin analysed by 2D NMR spectroscopy. Green Chem. 2015, 17, 244-249. [CrossRef]

50. Ouyang, X.-P.; Liu, C.-L.; Pang, Y.-X.; Qiu, X.-Q. Synthesis of a trimeric lignin model compound composed of $\alpha-\mathrm{O}-4$ and $\beta-\mathrm{O}-4$ linkages under microwave irradiation. Chin. Chem. Lett. 2013, 24, 1091-1094. [CrossRef]

51. Mimms, A.; Kocurek, M.; Pyatte, J.; Wright, E. (Eds.) Kraft Pulping Chemistry and Process; Tappi Press: Peachtree Corners, GA, USA, 1989.

52. Glasser, W.; Dave, V.; Frazier, C. Molecular weight distribution of (semi-)commercial lignin derivatives. J. Wood Chem. Technol. 1993, 13, 545-559. [CrossRef]

53. Pan, X.J.; Arato, C.; Gilkes, N.; Gregg, D.; Mabee, W.; Pye, K.; Xiao, Z.Z.; Zhang, X.; Saddler, J. Biorefining of softwoods using ethanol organosolv pulping: Preliminary evaluation of process streams for manufacture of fuel-grade ethanol and co-products. Biotechnol. Bioeng. 2005, 90, 473-481. [CrossRef] [PubMed]

54. Scholze, B.; Meier, D. Characterization of the water-insoluble fraction from pyrolysis oil (pyrolytic lignin). Part I. PY-GC/MS, FTIR, and functional groups. J. Anal. Appl. Pyrolysis 2001, 60, 41-54. [CrossRef]

55. Scholze, B.; Hanser, C.; Meier, D. Characterization of the water-insoluble fraction from fast pyrolysis liquids (pyrolytic lignin): Part II. GPC, carbonyl goups, and ${ }^{13}$ C NMR. J. Anal. Appl. Pyrolysis 2001, 58, 387-400. [CrossRef]

56. Samuel, R.; Pu, Y.; Raman, B.; Ragauskas, A. Structural characterization and comparison of switchgrass ball-milled lignin before and after dilute acid pretreatment. Appl. Biochem. Biotechnol. 2010, 162, 62-74. [CrossRef] [PubMed]

57. Saha, B.; Iten, L.; Cotta, M.; Wu, Y. Dilute acid pretreatment, enzymatic saccharification and fermentation of wheat straw to ethanol. Process Biochem. 2005, 40, 3693-3700. [CrossRef]

58. Chan, J.M.W.; Bauer, S.; Sorek, H.; Sreekumar, S.; Wang, K.; Toste, F.D. Studies on the vanadium-catalyzed nonoxidative depolymerization of miscanthus giganteus-derived lignin. ACS Catal. 2013, 3, 1369-1377. [CrossRef]

59. Díaz-Urrutia, C.; Chen, W.-C.; Crites, C.-O.; Daccache, J.; Korobkov, I.; Baker, R.T. Towards lignin valorisation: Comparing homogeneous catalysts for the aerobic oxidation and depolymerisation of organosolv lignin. RSC Adv. 2015, 5, 70502-70511. [CrossRef] 
60. Mottweiler, J.; Rinesch, T.; Besson, C.; Buendia, J.; Bolm, C. Iron-catalysed oxidative cleavage of lignin and ß-O-4 lignin model compounds with peroxides in DMSO. Green Chem. 2015, 17, 5001-5008. [CrossRef]

61. Zhou, X.-F.; Lu, X.-J. Co(salen) supported on graphene oxide for oxidation of lignin. J. Appl. Polym. Sci. 2016, 44133, 1-9. [CrossRef]

62. Mottweiler, J.; Puche, M.; Rauber, C.; Schmidt, T.; Concepcion, P.; Corma, A.; Bolm, C. Copper-and vanadium-Catalyzed oxidative cleavage of lignin using dioxygen. ChemSusChem 2015, 8, 2106-2113. [CrossRef] [PubMed]

63. Crestini, C.; Caponi, M.C.; Argyropoulos, D.S.; Saladino, R. Immobilized methyltrioxo rhenium (MTO)/H2O2 systems for the oxidation of lignin and lignin model compounds. Bioorg. Med. Chem. 2006, 14, 5292-5302. [CrossRef] [PubMed]

64. Gao, Y.; Zhang, J.; Chen, X.; Ma, D.; Yan, N. A metal-free, carbon-based catalytic system for the oxidation of lignin model compounds and lignin. ChemPlusChem 2014, 79, 825-834. [CrossRef]

65. Demesa, A.G.; Laari, A.; Turunen, I.; Sillanpää, M. Alkaline partial wet oxidation of lignin for the production of carboxylic acids. Chem. Eng. Technol. 2015, 38, 2270-2278. [CrossRef]

66. Ouyang, X.; Ruan, T.; Qiu, X. Effect of solvent on hydrothermal oxidation depolymerization of lignin for the production of monophenolic compounds. Fuel Process. Technol. 2016, 144, 181-185. [CrossRef]

67. Azarpira, A.; Ralph, J.; Lu, F. Catalytic alkaline oxidation of lignin and its model compounds: A pathway to aromatic biochemicals. BioEnergy Res. 2013, 7, 78-86. [CrossRef]

68. Voitl, T.; von Rohr, P.R. Oxidation of lignin using aqueous polyoxometalates in the presence of alcohols. ChemSusChem 2008, 1, 763-769. [CrossRef] [PubMed]

69. Voitl, T.; von Rohr, P.R. Demonstration of a process for the conversion of kraft lignin into vanillin and methyl vanillate by acidic oxidation in aqueous methanol. Ind. Eng. Chem. Res. 2010, 49, 520-525. [CrossRef]

70. Werhan, H.; Mir, J.M.; Voitl, T.; von Rohr, P.R. Acidic oxidation of kraft lignin into aromatic monomers catalyzed by transition metal salts. Holzforschung 2011, 65. [CrossRef]

71. Napoly, F.; Kardos, N.; Jean-Gérard, L.; Goux-Henry, C.; Andrioletti, B.; Draye, $\mathrm{M} . ~_{2} \mathrm{O}_{2}$-mediated kraft lignin oxidation with readily available metal salts: What about the effect of ultrasound? Ind. Eng. Chem. Res. 2015, 54, 6046-6051. [CrossRef]

72. Partenheimer, $\mathrm{W}$. The aerobic oxidative cleavage of lignin to produce hydroxyaromatic benzaldehydes and carboxylic acids via metal/bromide catalysts in acetic acid/water mixtures. Adv. Synth. Catal. 2009, 351, 456-466. [CrossRef]

73. Gu, X.; He, M.; Shi, Y.; Li, Z. La-modified SBA-15/ $\mathrm{H}_{2} \mathrm{O}_{2}$ systems for the microwave assisted oxidation of organosolv beech wood lignin. Maderas Cienc. Tecnol. 2012, 14, 31-41. [CrossRef]

74. Deng, W.; Zhang, H.; Wu, X.; Li, R.; Zhang, Q.; Wang, Y. Oxidative conversion of lignin and lignin model compounds catalyzed by CeO2-supported pd nanoparticles. Green Chem. 2015, 17, 5009-5018. [CrossRef]

75. Deng, H.; Lin, L.; Sun, Y.; Pang, C.; Zhuang, J.; Ouyang, P.; Li, Z.; Liu, S. Perovskite-type oxide $\mathrm{LaMnO}_{3}$ : An efficient and recyclable heterogeneous catalyst for the wet aerobic oxidation of lignin to aromatic aldehydes. Catal. Lett. 2008, 126, 106-111. [CrossRef]

76. Deng, H.; Lin, L.; Sun, Y.; Pang, C.; Zhuang, J.; Ouyang, P.; Li, J.; Liu, S. Activity and stability of perovskite-type oxide $\mathrm{LaCoO}_{3}$ catalyst in lignin catalytic wet oxidation to aromatic aldehydes process. Energy Fuels 2009, 23, 19-24. [CrossRef]

77. Dawange, M.; Galkin, M.V.; Samec, J.S.M. Selective aerobic benzylic alcohol oxidation of lignin model compounds: Route to aryl ketones. ChemCatChem 2015, 7, 401-404. [CrossRef]

78. Zhu, R.; Wang, B.; Cui, M.; Deng, J.; Li, X.; Ma, Y.; Fu, Y. Chemoselective oxidant-free dehydrogenation of alcohols in lignin using Cp*Ir catalysts. Green Chem. 2016, 18, 2029-2036. [CrossRef]

79. Cedeno, D.; Bozell, J. Catalytic oxidation of para-substituted phenols with cobalt-schiff base complexes $/ \mathrm{O}_{2}$-selective conversion of syringyl and guaiacyl lignin models to benzoquinones. Tetrahedron Lett. 2012, 53, 2380-2383. [CrossRef]

80. Badamali, S.; Luque, R.; Clark, J.; Breeden, S. Co(salen)/SBA-15 catalysed oxidation of a $\beta$-O-4 phenolic dimer under microwave irradiation. Catal. Commun. 2011, 12, 993-995. [CrossRef]

81. Crestini, C.; Pro, P.; Neri, V.; Saladino, R. Methyltrioxorhenium: A new catalyst for the activation of hydrogen peroxide to the oxidation of lignin and lignin model compounds. Bioorg. Med. Chem. 2005, 13, 2569-2578. [CrossRef] [PubMed] 
82. Ouyang, X.; Lin, Z.; Deng, Y.; Yang, D.; Qiu, X. Oxidative degradation of soda lignin assisted by microwave irradiation. Chin. J. Chem. Eng. 2010, 18, 695-702. [CrossRef]

83. Wu, A.; Lauzon, J.M.; Andriani, I.; James, B.R. Breakdown of lignins, lignin model compounds, and hydroxy-aromatics, to $\mathrm{C} 1$ and $\mathrm{C} 2$ chemicals via metal-free oxidation with peroxide or persulfate under mild conditions. RSC Adv. 2014, 4, 17931-17934. [CrossRef]

84. Maziero, P.; de Oliveira Neto, M.; Machado, D.; Batista, T.; Schmitt Cavalheiro, C.C.; Neumann, M.G.; Craievich, A.F.; de Moraes Rocha, G.J.; Polikarpov, I.; Gonçalves, A.R. Structural features of lignin obtained at different alkaline oxidation conditions from sugarcane bagasse. Ind. Crops Prod. 2012, 35, 61-69. [CrossRef]

85. Chen, C.; Pakdel, H.; Roy, C. Production of monomeric phenols by thermochemical conversion of biomass: A review. Bioresour. Technol. 2001, 79, 277-299. [CrossRef]

86. Bujanovic, B.; Reiner, R.S.; Ralph, S.A.; Atalla, R.H. Polyoxometalate delignification of birch kraft pulp and effect on residual lignin. J. Wood Chem. Technol. 2011, 31, 121-141. [CrossRef]

87. Sik Kim, Y.; Chang, H.-m.; Kadla, J.F. Polyoxometalate (POM) oxidation of milled wood lignin (MWL). J. Wood Chem. Technol. 2007, 27, 225-241. [CrossRef]

88. Partenheimer, W. Methodology and scope of metal bromide autoxidation of hydrocarbons. Catal. Today 1995, 23, 69-158. [CrossRef]

89. Rothenberg, G. Catalysis: Concepts and Green Applications; Wiely-VCH: Weinheim, Germany, 2008.

90. Ma, Y.; Du, Z.; Liu, J.; Xia, F.; Xu, J. Selective oxidative C-C bond cleavage of a lignin model compound in the presence of acetic acid with a vanadium catalyst. Green Chem. 2015, 17, 4968-4973. [CrossRef]

91. Pan, J.; Fu, J.; Lu, X. Microwave-assisted oxidative degradation of lignin model compounds with metal salts. Energy Fuels 2015, 29, 4503-4509. [CrossRef]

92. Shilpy, M.; Ehsan, M.A.; Ali, T.H.; Abd Hamid, S.B.; Ali, M.E. Performance of cobalt titanate towards $\mathrm{H}_{2} \mathrm{O}_{2}$ based catalytic oxidation of lignin model compound. RSC Adv. 2015, 5, 79644-79653. [CrossRef]

93. Tumula, V.; Bondwal, S.; Bisht, P.; Pendem, C.; Kumar, J. Oxidation of sulfides to sulfones with hydrogen peroxide in the presence of acetic acid and amberlyst 15. React. Kinet. Mech. Catal. 2012, 107, 449-466. [CrossRef]

94. Badamali, S.; Clark, J.; Breeden, S. Microwave assisted selective oxidation of lignin model phenolic monomer over SBA-15. Catal. Commun. 2008, 9, 2168-2170. [CrossRef]

95. Badamali, S.; Luque, R.; Clark, J.; Breeden, S. Microwave assisted oxidation of a lignin model phenolic monomer using Co(salen)/SBA-15. Catal. Commun. 2009, 10, 1010-1013. [CrossRef]

96. Badamali, S.K.; Luque, R.; Clark, J.H.; Breeden, S.W. Unprecedented oxidative properties of mesoporous silica materials: Towards microwave-assisted oxidation of lignin model compounds. Catal. Commun. 2013, 31, 1-4. [CrossRef]

97. Hanson, S.K.; Baker, R.T.; Gordon, J.C.; Scott, B.L.; Thorn, D.L. Aerobic oxidation of lignin models using a base metal vanadium catalyst. Inorg. Chem. 2010, 49, 5611-5618. [CrossRef] [PubMed]

98. Mate, V.R.; Shirai, M.; Rode, C.V. Heterogeneous $\mathrm{Co}_{3} \mathrm{O}_{4}$ catalyst for selective oxidation of aqueous veratryl alcohol using molecular oxygen. Catal. Commun. 2013, 33, 66-69. [CrossRef]

99. Mate, V.R.; Jha, A.; Joshi, U.D.; Patil, K.R.; Shirai, M.; Rode, C.V. Effect of preparation parameters on characterization and activity of $\mathrm{Co}_{3} \mathrm{O}_{4}$ catalyst in liquid phase oxidation of lignin model substrates. Appl. Catal. A 2014, 487, 130-138. [CrossRef]

100. Gu, X.; He, M.; Shi, Y.; Li, Z. La-containing SBA-15/ $\mathrm{H}_{2} \mathrm{O}_{2}$ systems for the microwave assisted oxidation of a lignin model phenolic monomer. Maderas Cienc. Tecnol. 2010, 12, 181-188. [CrossRef]

101. Gu, X.; He, M.; Shi, Y.; Li, Z. Production of armotic aldehyde by microwave catalytic oxidation of a lignin model compound with La-containing SBA-15/ $\mathrm{H}_{2} \mathrm{O}_{2}$ systems. BioResources 2010, 5, 2029-2039.

102. Lanfranchi, M.; Prati, L.; Rossi, M.; Tiripicchio, A. The oxidation of ethane-1,2-diol resulting from molecular oxygen activation by copper: Formation of an oxoethanoate complex precedes carbon-carbon bond cleavage. J. Chem. Soc. Chem. Commun. 1993, 22, 1698-1699. [CrossRef]

103. Prati, L.; Rossi, M. Stepwise oxidation of 1,2-diols resulting from molecular oxygen activation by copper. J. Mol. Catal. A 1996, 110, 221-226. [CrossRef]

104. Hanson, S.K.; Baker, R.T. Knocking on wood: Base metal complexes as catalysts for selective oxidation of lignin models and extracts. Acc. Chem. Res. 2015, 48, 2037-2048. [CrossRef] [PubMed] 
105. Elkurtehi, A.I.; Walsh, A.G.; Dawe, L.N.; Kerton, F.M. Vanadium aminophenolate complexes and their catalytic activity in aerobic and $\mathrm{H}_{2} \mathrm{O}_{2}$-mediated oxidation reactions. Eur. J. Inorg. Chem. 2016, 2016, 3123-3130. [CrossRef]

106. Ede, R.M.; Ralph, J.; Torr, K.M.; Dawson, B.S.W. A 2D NMR investigation of the heterogeneity of distribution of diarylpropane structures in extracted pinus radiata lignins. Holzforschung 1996, 50, 161-164.

107. Hanson, S.K.; Baker, R.T.; Gordon, J.C.; Scott, B.L.; Silks, L.A.P.; Thorn, D.L. Mechanism of alcohol oxidation by dipicolinate vanadium(V): Unexpected role of pyridine. J. Am. Chem. Soc. 2010, 132, 17804-17816. [CrossRef] [PubMed]

108. Haibach, M.C.; Lease, N.; Goldman, A.S. Catalytic cleavage of ether C-O bonds by pincer iridium complexes. Angew. Chem. Int. Ed. 2014, 53, 10160-10163. [CrossRef] [PubMed]

109. Díaz-Urrutia, C.; Sedai, B.; Leckett, K.C.; Baker, R.T.; Hanson, S.K. Aerobic oxidation of 2-phenoxyethanol lignin model compounds using vanadium and copper catalysts. ACS Sustain. Chem. Eng. 2016, 4, 6244-6251. [CrossRef]

110. Ma, Y.; Du, Z.; Xia, F.; Ma, J.; Gao, J.; Xu, J. Mechanistic studies on the VO(acac)2-catalyzed oxidative cleavage of lignin model compounds in acetic acid. RSC Adv. 2016, 6, 110229-110234. [CrossRef]

111. Blandez, J.F.; Navalón, S.; Alvaro, M.; Garcia, H. Graphenes as metal-free catalysts for the oxidative depolymerization of lignin models. ChemCatChem 2015, 7, 3020-3026. [CrossRef]

112. Son, S.; Toste, F.D. Non-oxidative vanadium-catalyzed C-O bond cleavage: Application to degradation of lignin model compounds. Angew. Chem. Int. Ed. 2010, 49, 3791-3794. [CrossRef] [PubMed]

113. Vom Stein, T.; Hartog, T.; Buendia, J.; Stoychev, S.; Mottweiler, J.; Bolm, C.; Leitner, W. Ruthenium-catalyzed C-C bond cleavage in lignin model substrates. Angew. Chem. Int. Ed. 2015, 54, 5859-5863. [CrossRef] [PubMed]

114. Sung, K.; Huh, S.; Jun, M. Syntheses of ruthenium(II) complexes containing polyphosphine ligands and their applications in the homogeneous hydrogenation. Polyhedron 1999, 18, 469-479. [CrossRef]

115. Hanson, S.K.; Wu, R.; Silks, L.A. C-C or C-O bond cleavage in a phenolic lignin model compound: Selectivity depends on vanadium catalyst. Angew. Chem. Int. Ed. 2012, 51, 3410-3413. [CrossRef] [PubMed]

116. Jiang, Y.-Y.; Yan, L.; Yu, H.-Z.; Zhang, Q.; Fu, Y. Mechanism of vanadium-catalyzed selective C-O and C-C cleavage of lignin model compound. ACS Catal. 2016, 6, 4399-4410. [CrossRef]

117. Parker, H.J.; Chuck, C.J.; Woodman, T.; Jones, M.D. Degradation of $\beta-O-4$ model lignin species by vanadium Schiff-base catalysts: Influence of catalyst structure and reaction conditions on activity and selectivity. Catal. Today 2016, 269, 40-47. [CrossRef]

118. Wang, M.; Lu, J.; Zhang, X.; Li, L.; Li, H.; Luo, N.; Wang, F. Two-step, catalytic C-C bond oxidative cleavage process converts lignin models and extracts to aromatic acids. ACS Catal. 2016, 6, 6086-6090. [CrossRef] 